\title{
Neoglacial climate anomalies and the Harappan metamorphosis
}

\author{
Liviu Giosan ${ }^{1}$, William D. Orsi' ${ }^{2,3}$, Marco Coolen ${ }^{4}$, Cornelia Wuchter ${ }^{4}$, Ann G. Dunlea ${ }^{1}$, Kaustubh Thirumalai ${ }^{5}$, \\ Samuel E. Munoz ${ }^{1}$, Peter D. Clift ${ }^{6}$, Jeffrey P. Donnelly ${ }^{1}$, Valier Galy ${ }^{7}$, and Dorian Q. Fuller ${ }^{8}$ \\ ${ }^{1}$ Geology \& Geophysics, Woods Hole Oceanographic Institution, Woods Hole, MA, USA \\ ${ }^{2}$ Department of Earth and Environmental Sciences, Paleontology \& Geobiology, Ludwig-Maximilians-Universität München, \\ Munich, Germany \\ ${ }^{3}$ GeoBio-CenterLMU, Ludwig-Maximilians-Universität München, Munich, Germany \\ ${ }^{4}$ Faculty of Science and Engineering, Curtin University, Perth, Australia \\ ${ }^{5}$ Department of Earth, Environmental, and Planetary Sciences, Brown University, Providence, RI, USA \\ ${ }^{6}$ Geology \& Geophysics, Louisiana State University, USA \\ ${ }^{7}$ Marine Chemistry \& Geochemistry, Woods Hole Oceanographic Institution, Woods Hole, MA, USA \\ ${ }^{8}$ Institute of Archaeology, University College London, London, UK
}

Correspondence: Liviu Giosan (lgiosan@whoi.edu)

Received: 26 March 2018 - Discussion started: 4 April 2018

Revised: 17 October 2018 - Accepted: 18 October 2018 - Published: 13 November 2018

\begin{abstract}
Climate exerted constraints on the growth and decline of past human societies but our knowledge of temporal and spatial climatic patterns is often too restricted to address causal connections. At a global scale, the inter-hemispheric thermal balance provides an emergent framework for understanding regional Holocene climate variability. As the thermal balance adjusted to gradual changes in the seasonality of insolation, the Intertropical Convergence Zone migrated southward accompanied by a weakening of the Indian summer monsoon. Superimposed on this trend, anomalies such as the Little Ice Age point to asymmetric changes in the extratropics of either hemisphere. Here we present a reconstruction of the Indian winter monsoon in the Arabian Sea for the last 6000 years based on paleobiological records in sediments from the continental margin of Pakistan at two levels of ecological complexity: sedimentary ancient DNA reflecting water column environmental states and planktonic foraminifers sensitive to winter conditions. We show that strong winter monsoons between ca. 4500 and 3000 years ago occurred during a period characterized by a series of weak interhemispheric temperature contrast intervals, which we identify as the early neoglacial anomalies (ENA). The strong winter monsoons during ENA were accompanied by changes in wind and precipitation patterns that are particularly evident across the eastern Northern Hemisphere and tropics. This coordinated climate reorganization may have
\end{abstract}

helped trigger the metamorphosis of the urban Harappan civilization into a rural society through a push-pull migration from summer flood-deficient river valleys to the Himalayan piedmont plains with augmented winter rains. The decline in the winter monsoon between 3300 and 3000 years ago at the end of ENA could have played a role in the demise of the rural late Harappans during that time as the first Iron Age culture established itself on the Ghaggar-Hakra interfluve. Finally, we speculate that time-transgressive land cover changes due to aridification of the tropics may have led to a generalized instability of the global climate during ENA at the transition from the warmer Holocene thermal maximum to the cooler Neoglacial.

\section{Introduction}

The growth and decline of human societies can be affected by climate (e.g., Butzer, 2012; deMenocal, 2001) but addressing causal connections is difficult, especially when no written records exist. Human agency sometimes confounds such connections by acting to mitigate climate pressures or, on the contrary, increasing the brittleness of social systems in face of climate variability (Rosen, 2007). Moreover, our knowledge of temporal and spatial climatic patterns remains too restricted, especially deeper in time, to fully address so- 
cial dynamics. Significant progress in addressing this problem has been made especially for historical intervals (e.g., Carey, 2012; McMichael, 2012; Brooke, 2014; Izdebski et al., 2016; d'Alpoim Guedes et al., 2016; Nelson et al., 2016; Ljungqvist, 2017; Haldon et al., 2018) using theoretical reconsiderations, novel sources of data and sophisticated deep time modeling that could lead to better consilience between natural scientists, historians and archaeologists. The coalescence of migration phenomena, profound cultural transformations and/or collapse of prehistorical societies regardless of geographical and cultural boundaries during certain time periods characterized by climatic anomalies, events or regime shifts suggests that large scale climate variability may be involved (e.g., Donges et al., 2015 and references therein). At the global scale, the interhemispheric thermal balance provides an emergent framework for understanding such major Holocene climate events (Boos and Korty, 2016; Broecker and Putnam, 2013; McGee et al., 2014; Schneider et al., 2014). As this balance adjusted over the Holocene to gradual changes in the seasonality of insolation (Berger and Loutre, 1991), the Intertropical Convergence Zone (ITCZ) migrated southward (e.g., Arbuszewski et al., 2013; Haug et al., 2001) accompanied by a weakening of the Indian summer monsoon (e.g., Fleitmann et al., 2003; Ponton et al., 2012). Superimposed on this trend, centennial- to millennial-scale anomalies point to asymmetric changes in the extratropics of either hemisphere (Boos and Korty, 2016; Broccoli et al., 2006; Chiang and Bitz, 2005; Schneider et al., 2014).

The most extensive but least understood among the early urban civilizations, the Harappan (Figs. 1 and 2; see Supplement for distribution of archaeological sites), collapsed ca. 3900 years ago (e.g., Shaffer, 1992). At their peak, the Harappans spread over the alluvial plain of the Indus and its tributaries, encroaching onto the Sutlej-Yamuna or GhaggarHakra (G-H) interfluve that separates the Indus and Ganges drainage basins (Fig. 1; see more information on the Harappans in Appendix A). In the late Harappan phase that was characterized by more regional artefact styles and trading networks, cities and settlements along the Indus and its tributaries declined while the number of rural sites increased on the upper G-H interfluve (Gangal et al., 2010; Kenoyer, 1998; Mughal, 1997; Possehl, 2002; Wright, 2010). The agricultural Harappan economy showed a large degree of versatility by adapting to water availability (e.g., Fuller, 2011; Giosan et al., 2012; Madella and Fuller, 2006; Petrie et al., 2017; Weber et al., 2010; Wright et al., 2008). Two precipitation sources, the summer monsoon and winter westerlies (Fig. 1), provide rainfall to the region (Bookhagen and Burbank, 2010; Petrie et al., 2017; Wright et al., 2008). Previous simple modeling exercises suggested that winter rain increased in Punjab over the late Holocene (Wright et al., 2008). During the hydrologic year, part of this precipitation, stored as snow and ice in surrounding mountain ranges, is redistributed as meltwater by the Indus and its Himalayan tributaries to the arid and semi-arid landscape of the alluvial plain (Karim and Veizer, 2002).

The climatic trigger for the urban Harappan collapse was probably the decline of the summer monsoon (e.g., Dixit et al., 2014; Kathayat et al., 2017; MacDonald, 2011; Singh et al., 1971; Staubwasser et al., 2003; Stein, 1931) that led to less extensive and more erratic floods, making inundation agriculture less sustainable along the Indus and its tributaries (Giosan et al., 2012) and may have led to bio-socioeconomic stress and disruptions (e.g., Meadow, 1991; Schug et al., 2013). Still, the remarkable longevity of the decentralized rural phase until ca. 3200 years ago, in the face of persistent late Holocene aridity (Dixit et al., 2014; Fleitmann et al., 2003; Ponton et al., 2012; Prasad and Enzel, 2006), remains puzzling. Whether the Harappan metamorphosis was simply the result of habitat tracking toward regions where summer monsoon floods were still reliable or also reflected a significant increase in winter rain remains unknown (Giosan et al., 2012; Madella and Fuller, 2006; Petrie et al., 2017; Wright et al., 2008). To address this dilemma, we present a proxy record for the Indian winter monsoon in the Arabian Sea and show that its variability was an expression of large scale climate reorganization across the eastern Northern Hemisphere and tropics affecting precipitation patterns across the Harappan territory. Aided by an analysis of Harappan archaeological site redistribution, we speculate that the Harappan relocation after the collapse of its urban phase may have conformed to a push-pull migration model.

\section{Background}

Under modern climatological conditions (Fig. 3), the summer monsoon delivers most of the precipitation to the former Harappan territory, but winter rains are also significant in quantity along the Himalayan piedmont (i.e., between $15 \%$ and $30 \%$ annually). Winter rain is brought in primarily by extra-tropical cyclones embedded in the westerlies (Dimri et al., 2015) and are known locally as western disturbances (WD). These cyclones distribute winter rains to a zonal swath extending from the Mediterranean through Mesopotamia, the Iranian Plateau and Balochistan, all and across to the western Himalayas (Fig. 3). Stronger and more frequent WD rains in northwestern India are associated with southern shifts of the westerly jet in the upper troposphere (e.g., Dimri et al., 2015). Surface winter monsoon winds are generally directed towards the southwest but they blow preferentially toward the east-southeast along the coast in the northernmost Arabian Sea (Fig. 3). An enhanced eastward zonal component over the northern Arabian Sea is typical for more rainy winters (Dimri et al., 2017). Although limited in space and time, modern climatologies indicate a strong, physical linkage between winter sea-surface temperatures (SST) in the northern Arabian Sea and precipitation on the Himalayan piedmont, including the upper G-H interfluve (see also Supplement). 


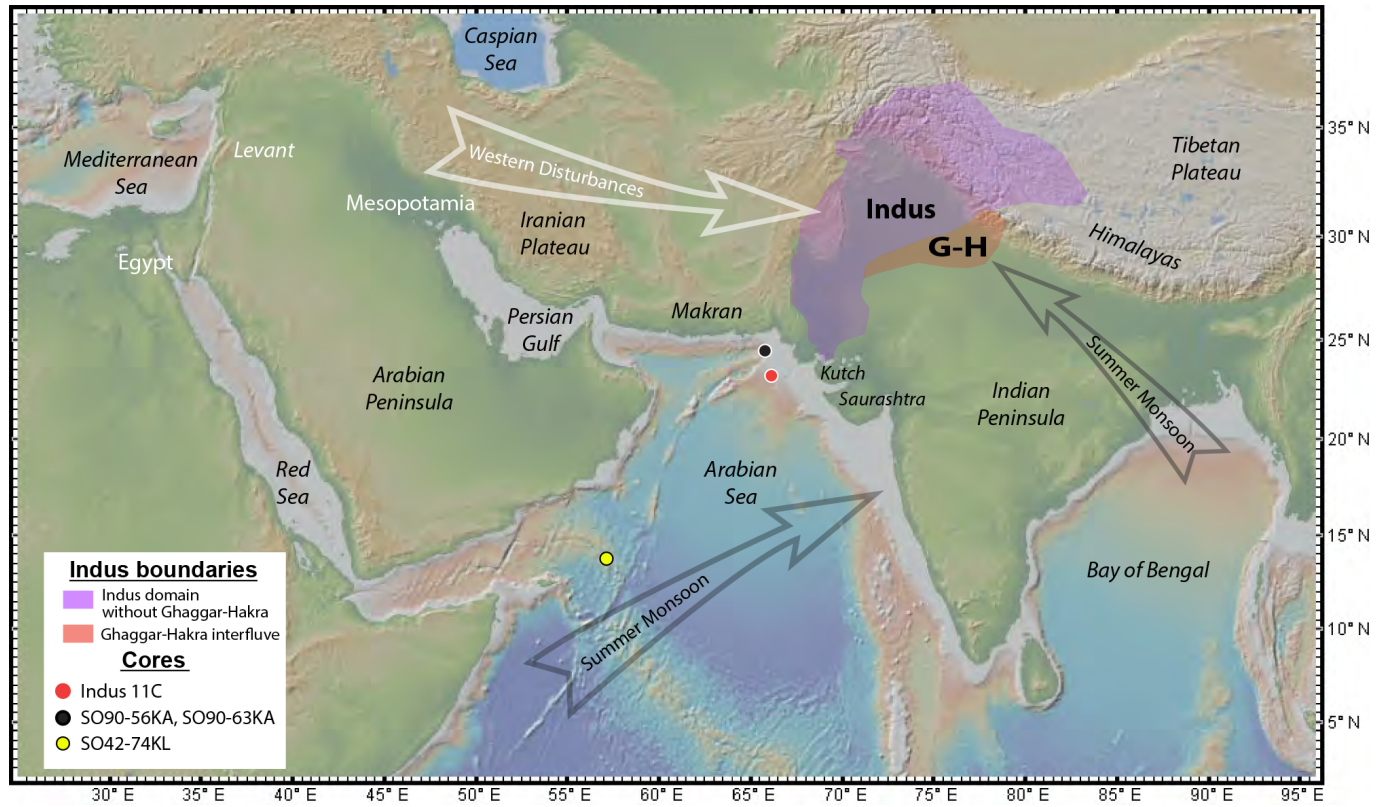

Figure 1. Physiography, winds and precipitation sources for the Harappan domain. The dominant source during summer monsoon is the Bay of Bengal while western disturbances provide the moisture during winter. The extent of the Indus basin and Ghaggar-Hakra (G-H) interfluve are shown with purple and brown masks, respectively. Locations for the cores discussed in the text are shown.

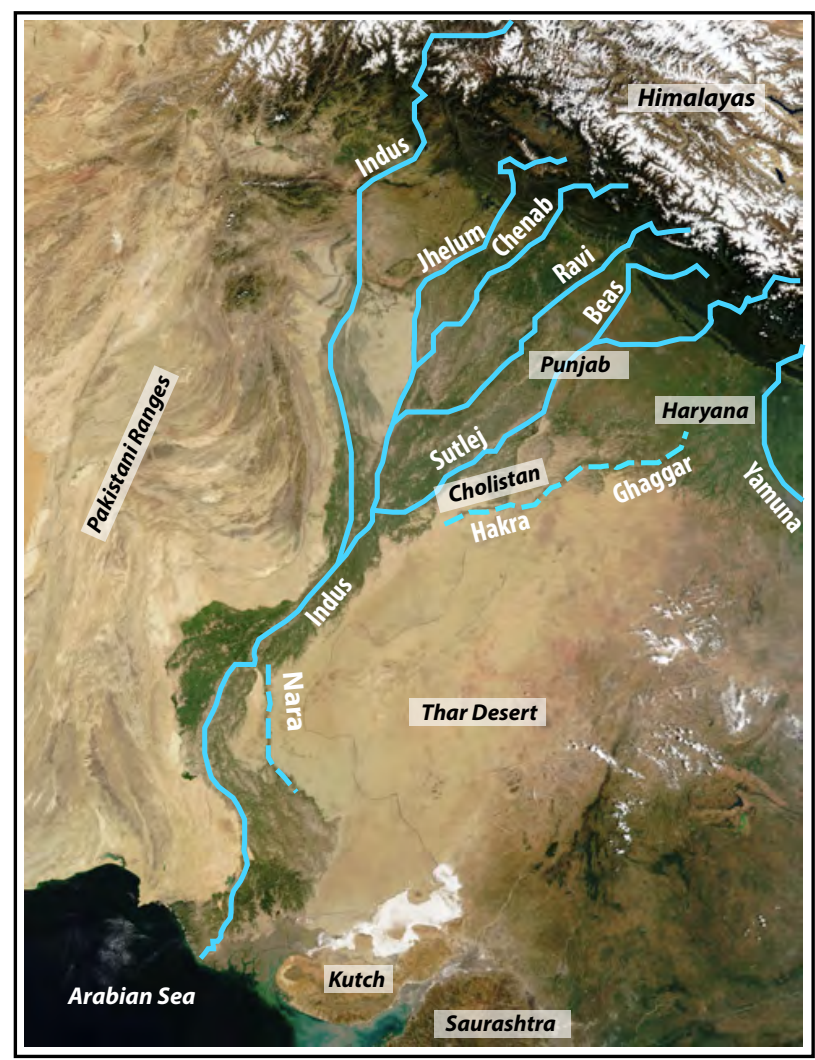

Figure 2. Geographical regions and rivers of the Indus domain discussed in text.
Ultimately, the thermal contrast between the cold Asian continent and relatively warmer Indian Ocean is thought to be the initial driver of the Indian monsoon winds (Dimri et al., 2006).

In contrast to the wet summer monsoon, winds of the winter monsoon flow from the continent toward the ocean and are generally dry. That explains in part why Holocene reconstructions of the winter monsoon are few and contradictory, suggesting strong regional variabilities (Jia et al., 2015; Kotlia et al., 2017; Li and Morrill, 2015; Wang et al., 2012). Holocene eolian deposits linked to the winter monsoon are also geographically limited ( $\mathrm{Li}$ and Morrill, 2015). However, in the Arabian Sea indirect wind proxies based on changes in planktonic foraminifer assemblages and other mixing properties have been used to reconstruct distinct hydrographic states caused by seasonal winds (Böll et al., 2014; Curry et al., 1992; Lückge et al., 2001; Munz et al., 2015; Schiebel et al., 2004; Schulz et al., 2002). Winter monsoon winds blowing over the northeastern Arabian Sea cool its surface waters via evaporation and weaken thermal stratification promoting convective mixing (Banse and McClain, 1986; Luis and Kawamura, 2004). Cooler SSTs and the injection of nutrients into the photic zone lead in turn to changes in the plankton community (Madhupratap et al., 1996; Luis and Kawamura, 2004; Schulz et al., 2002). To reconstruct the history of winter monsoon we thus employed complementary proxies for convective winter mixing, at two levels of ecological complexity: (a) sedimentary ancient DNA to assess the water column plankton community structure, and (b) the relative abundance of Globigerina falconensis, a planktonic foraminifer 

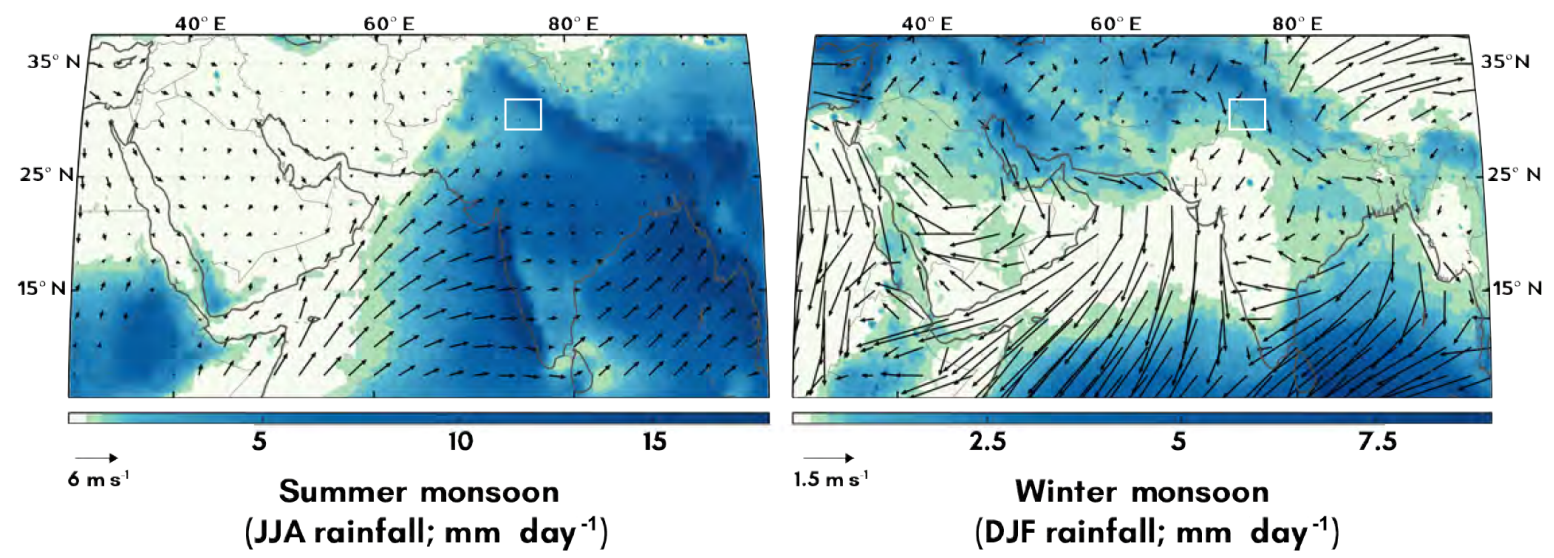

Figure 3. Modern seasonal climatology for South Asia. Average precipitation as well as wind direction and intensity for the summer (JuneJuly-August or JJA) and winter (December-January-February or DJF) months are presented in the left and right panels, respectively. Note the differences in scales between panels for both rainfall and winds. Data used come from the ERA-40 reanalysis dataset (Uppala et al., 2005) for winds (averaged from 1958-2001) and the TRMM dataset (Huffman et al., 2007) for rainfall (averaged from 1998-2014). The white box encompasses the upper G-H interfluve.

sensitive to winter conditions (Munz et al., 2015; Schulz et al., 2002).

\section{Methods}

\subsection{Sediment core}

We sampled the upper $2.3 \mathrm{~m}$, comprising the Holocene inter$\mathrm{val}$, in the $13 \mathrm{~m}$-long piston core Indus 11C (Clift et al., 2014) retrieved during R/V Pelagia cruise 64PE300 in 2009 from the oxygen minimum zone (OMZ) in the northeastern Arabian Sea $\left(23^{\circ} 07.30^{\prime} \mathrm{N}, 66^{\circ} 29.80^{\prime} \mathrm{E}\right.$; $566 \mathrm{~m}$ depth) (Fig. 1). The chronology for the Holocene section of the core was previously reported in Orsi et al. (2017) and is based on calibrated radiocarbon dates of five multi-specimen samples of planktonic foram Orbulina universa and one mixed planktonic foraminifer sample. Calibration was performed using Calib 7.1 program (Stuiver et al., 2018) with a reservoir age of $565 \pm 35$ radiocarbon years following regional reservoir reconstructions by Staubwasser et al. (2002). Calibrated radiocarbon dates were used to derive a polynomial age model (see Supplement). The piston corer did not recover the last few hundred years of the Holocene record probably due to overpenetration. However, indistinct but continuous laminations downcore with no visual or X-radiograph discontinuities, together with the radiocarbon chronology, indicate that the sedimentary record recovered is continuous.

\subsection{Ancient DNA analyses}

A total of $5 \mathrm{~g}$ of wet weight sediment were extracted inside the ancient DNA-dedicated lab at Woods Hole Oceanographic Institution (WHOI), aseptically as described previously (Coolen et al., 2013) and transferred into $50 \mathrm{~mL}$ sterile tubes. The sediments were homogenized for $40 \mathrm{~s}$ at speed 6 using a Fastprep 96 homogenizer (MP Biomedicals, Santa Ana, CA) in the presence of beads and $15 \mathrm{~mL}$ of preheated $\left(50^{\circ} \mathrm{C}\right)$ sterile filtered extraction buffer: 77 vol $\% 1 \mathrm{M}$ phosphate buffer $\mathrm{pH} 8,15 \mathrm{vol} \% 200$ proof ethanol and $8 \mathrm{vol} \%$ of MoBio's lysis buffer solution C1 (MoBio, Carlsbad, CA). The extraction was repeated with $10 \mathrm{~mL}$ of the same extraction buffer but without $\mathrm{C} 1$ lysis buffer (Orsi et al., 2017). After centrifugation, the supernatants were pooled and concentrated to a volume of $100 \mu \mathrm{L}$ without loss of DNA using $50000 \mathrm{NMWL}$ Amicon ${ }^{\circledR}$ Ultra $15 \mathrm{~mL}$ centrifugal filters (Millipore) and contaminants were removed from the concentrated extract using the PowerClean ${ }^{\circledR}$ Pro DNA Clean-up Kit (MoBio). The exact same procedures were performed in triplicate without the addition of sediment as a control for contamination during extraction and purification of the sedimentary DNA.

The extracted and purified sedimentary DNA was quantified fluorometrically using Quant-iT PicoGreen dsDNA Reagent (Invitrogen), and $\sim 20$ nanograms of each extract was used as template for PCR amplification of preserved planktonic 18S rRNA genes. The short ( $\sim 130$ base pair) $18 \mathrm{~S}$ rDNA-V9 region was amplified using the domain-specific primer combination 1380F (5'-CCC TGC CHT TTG TAC ACA C-3') and 1510R (5'CCT TCY GCA GGT TCA CCT AC-3'; Amaral-Zettler et al., 2009). Quantitative PCR was performed using a SYBR ${ }^{\circledR}$ Green I nucleic acid stain (Invitrogen) and using a Realplex quantitative PCR system (Eppendorf, Hauppauge, NY). The annealing temperature was set to $66^{\circ} \mathrm{C}$ and all reactions were stopped in the exponential phase after $35-42$ cycles. The $18 \mathrm{~S}$ rRNA libraries were sequenced on an Illumina MiSeq sequencing using the facilities of the W.M. Keck Center for Comparative and Functional Genomics, University of Illinois at Urbana-Champaign, IL, 
USA, sequenced $18 \mathrm{~S}$ libraries that resulted in approximately 12 million DNA sequences.

The 18S rRNA gene sequences were processed using the Quantitative Insights Into Microbial Ecology (QIIME) environment (Caporaso et al., 2010). Reads passing quality control (removal of any sequence containing an "N", minimum read length $250 \mathrm{bp}$, minimum Phred score = 20) were organized into operational taxonomic units (OTUs) sharing $95 \%$ sequence identity with UCLUST (Edgar, 2010) and assigned to taxonomic groups through BLASTn searches against the SILVA database (Pruesse et al., 2007). OTU tables were rarefied to the sample with the least number of sequences, and all OTUs containing less than one sequence were removed. OTUs that were detected in only one sample were also removed. Metagenomes were directly sequenced bi-directionally on an Illumina HiSeq, at the University of Delaware Sequencing and Genotyping Center (Delaware Biotechnology Institute). Contigs were assembled de novo as described in Orsi et al. (2017). To identify contigs containing chlorophyll biosynthesis proteins, open reading frames on the contig sequences were detected using FragGeneScan (Rho et al., 2010), and protein homologs were identified through BLASTp searches against the SEED database (http: //www.theseed.org/wiki/Main_Page, last access: 26 October 2018). Only hits to reference proteins with at least $60 \%$ amino acid similarity over an alignment length $>50$ amino acids were considered true homologs and used for downstream analysis. Assignment of ORFs to biochemical pathway classes were made based on the SEED metabolic pathway database and classification scheme. The relative abundance of reads mapping to ORFs was normalized against values of a suite of 35 universally conserved single copy genes (Orsi et al., 2015), per metagenome sample.

\subsection{Factor analysis}

Q-mode factor analysis (QFA) was employed to simplify the ancient DNA dataset. Prior to the factor analysis, the DNA database was reduced to the 124 most abundant taxonomic units from a total of 1462 units identified by considering only those present in two or more samples with a cumulative abundance higher than $0.5 \pm 0.1 \%$ (Table S1 in the Supplement). The data were pretreated with a range normalization and run though the QFA with a VARIMAX rotation (Pisias et al., 2013). QFA identified taxonomic groups that co-vary in our dataset and determined the minimum number of components (i.e., factors) needed to explain a given fraction of the variance of the data set (Fig. 4; see Supplement). Each VARIMAX-rotated factor indicates an association of taxonomic groups that co-vary (i.e., behave similarly amongst the samples). Taxonomic groups that co-vary strongly within a factor will have high factor scores for that factor. We primarily used dominant taxa with scores higher than 0.2 in a factor to interpret the plankton taxonomic groups in that factor. The importance of a factor in any given sample is recorded by the
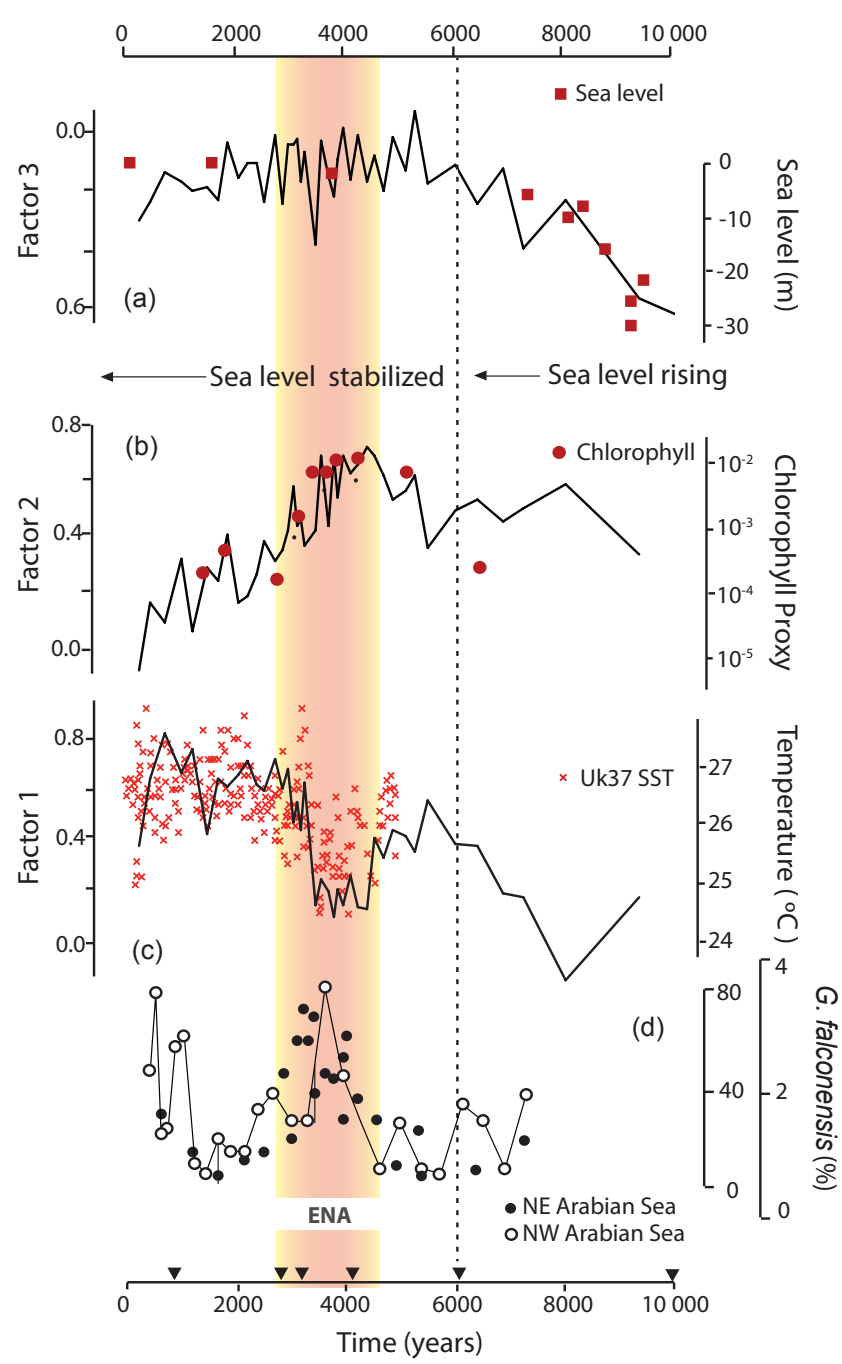

Figure 4. Holocene variability in plankton communities as reflected by their sedimentary DNA factor loadings $(\mathbf{a}-\mathbf{c})$ and winter mixingsensitive percentage G. falconensis (d) in core Indus $11 \mathrm{C}$ in the northeastern Arabian Sea. Relative chlorophyll biosynthesis proteins abundances are also shown. Sea level points are from Camoin et al. (2004); SSTs are from Doose-Rolinski et al. (2001); and G. falconensis census from the northwestern Arabian Sea is from Schulz et al. (2002). Triangles show radiocarbon dates for core Indus $11 \mathrm{C}$. The period corresponding to the early neoglacial anomalies (ENA) is shaded in red hues.

factor loading that we used to interpret the importance of that factor with depth and time downcore.

\subsection{Foraminifera counts}

Samples for counting planktonic foraminifer Globigerina falconensis were wet-sieved over a $63 \mu \mathrm{m}$ screen. Typical planktonic foraminifer assemblages for the northeastern Arabian Sea were observed: Globigerinoides ruber, Neogloboquadrina dutertrei, Globigerina falconensis, Orbulina uni- 
versa, Globigerinoides sacculifer, Pulleniatina obliquiloculata, Globorotalia menardii. Counts of Globigerina falconensis were conducted on the size fraction $>150 \mu \mathrm{m}$. We report counts for the samples yielding $>300$ foraminifer individuals (see Supplement).

\subsection{Harappan sites}

Archaeological site distribution provides an important line of evidence for social changes in the Harappan domain (e.g., Possehl, 2000). We analyzed the redistribution of small $(<$ $20 \mathrm{ha}$ ), rural vs. large ( $>20 \mathrm{ha}$ ), possibly urban sites on the G-H interfluve from the Early Harappan period, through the Mature and Late periods to the post-Harappan Grey Ware culture (see Supplement). Compared to settlements along the Indus and its tributaries that can be affected by fluvial erosion (Giosan et al., 2012), the distribution of archaeological sites on G-H, where large laterally incising Himalayan rivers were absent during the Holocene, is probably more complete and representative of their original distribution. To observe trends related to partial or complete drying of the G-H system (Clift et al., 2012; Giosan et al., 2012; Singh et al., 2017), we divided the settlements into upper and lower G-H sites located in the modern regions of Punjab and Haryana in India, and Cholistan in Pakistan, respectively. For archaeological site locations and their radiocarbon and/or archaeological ages we follow Giosan et al. (2012), using data from the compilation by Gangal et al. (2010) with additions from regional gazetteers and surveys (Kumar, 2009; Mallah, 2010; Mughal, 1996, 1997; Possehl, 1999; Wright et al., 2005).

\section{Results}

Exceptional preservation of organic matter in the OMZ (Altabet et al., 1995; Schulz et al., 2002) allowed us to reconstruct the history of the planktonic communities based on their preserved sedimentary DNA (see also Orsi et al., 2017). The factor analysis of the dominant DNA species (Fig. 4) identified three significant factors that together explain $48 \%$ of the variability in the dataset (see Supplement). Additional factors were excluded as they would have increased the variability explained by an insignificant amount for each $(<$ $3 \%$ ). We interpret these factors as corresponding to the SST regime, nutrient availability and sea level state, respectively (Fig. 4). Factor 1 (Fig. 4c) explains $20 \%$ of the variability and is largely dominated by radiolarians (Polycystinea) that prefer warmer sea surface conditions (e.g., Cortese and Ablemann, 2002; Kamikuri et al., 2008). High scores for jellyfish (Cnidaria) that thrive in warm, eutrophic waters (Purcell, 2005) also support interpreting Factor 1 as a proxy for a plankton community adapted to high sea surface temperatures. A general increase of the Factor 1 loadings since the early Holocene is in accordance with the $\mathrm{U}_{37}^{K}$-reconstructed warming of Orsi et al. (2017). During the Holocene, relatively colder conditions are evident in Factor 1 between $\sim 4500$ and 3000 years ago (Fig. 4) as previously detected in the higher resolution $\mathrm{U}_{37}^{K}$ record from a core located nearby on the Makran continental margin (Doose-Rolinski et al., 2001).

Factor 2 (Fig. 4b) explains $18 \%$ of the variability and is dominated by marine dinoflagellates indicative of high nutrient, bloom conditions (e.g., Worden et al., 2015), flagellates (Cercozoa) and fungi. Parasitic Alveolates (Hematodinium and Syndiniales) that typically appear during blooms (Worden et al., 2015) are also important. Increased representation of chlorophyll biosynthesis genes (Fig. 4) in sediment metagenomes (Orsi et al., 2017) indicate higher productivity (Worden et al., 2015) during the Factor 2 peak. All these associations suggest that Factor 2 is a nutrient-sensitive proxy with a peak that overlaps with the colder conditions between $\sim 4500$ and 3000 years ago. The inland retreat of the Indus fluvial nutrient source as sea level rose (see below) probably explains the asymmetry in Factor 2 that exhibits higher scores in the early vs. late Holocene. Overall, Factors 1 and 2 suggests enhanced winter convective mixing between $\sim 4500$ and 3000 years ago that brought colder, nutrient-rich waters to the surface.

Factor 3 (Fig. 4a) explains $10 \%$ variability and is dominated by a wide group of taxa. The main identified contributors to Factor 3 include the coastal diatom Eucampia (Werner, 1977), the fish-egg parasite dinoflagellate Ichthyodinium, also reported from coastal habitats (Shadrin, 2010) and soil ciliates (Colpodida), which altogether suggest a nearshore environment with fluvial inputs. The plankton community described by Factor 3 was dominant in the first half of the Holocene and became scarce as the sea level rose (Camoin et al., 2004) and the Indus coast retreated inland (Fig. 4) .

At a simpler ecological level, Globigerina falconensis is the dominant planktonic foraminifer in the northeastern Arabian Sea under strong winter wind mixing conditions (Munz et al., 2015; Schulz et al., 2002). Over the last six millennia, after the sea level approached the present level, and when the plankton community was consistently outside the influence of coastal and fluvial processes, $G$. falconensis shows a peak in relative abundance between $\sim 4500$ and 3000 years during the cold reversal previously identified by the sedimentary ancient DNA (Fig. 4d). A similar peak in G. falconensis was detected in core SO42-74KL from the western Arabian Sea upwelling area (Schulz et al., 2002) suggesting that mixing occurred in the whole northern half of the Arabian Sea (Fig. 4d).

\section{Discussion}

\subsection{Winter monsoon variability in the Neoglacial}

In concert with previous data from the northern Arabian Sea, our reconstructions suggest that convective mixing conditions indicative of a stronger winter monsoon occurred be- 
tween $\sim 4500$ and 3000 years ago. Another cold yet variable period in the northern Arabian Sea (Doose-Rolinski et al., 2001) occurred after $\sim 1500$ years ago under strong winter monsoon mixing (Böll et al., 2014; Munz et al., 2015 ) and is seen in the G. falconensis record of Schulz et al. (2002) but is not captured completely in our top incomplete record. In accordance with modern climatologies colder SSTs in the northern coastal Arabian Sea correspond to increased westerly extratropical cyclones bringing winter rains as far as Balochistan and the western Himalayas (Figs. 3 and S1). Pollen records offshore the Makran coast where rivers from Balochistan and ephemeral streams flood during winter (von Rad et al., 1999) indeed indicate enhanced winter monsoon precipitation during between $\sim 4500$ and 3000 years ago (Ivory and Lezine, 2009). Bulk chemistry of sediments from the same Makran core were used to infer enhanced winter-monsoon conditions between 3900 and 3000 years ago (Lückge et al., 2001). Although not specifically identified as winter precipitation, increased moisture between $\sim 4600$ and 2500 years ago was also documented immediately east of the Indus River mouths in the now arid Rann of Kutch (Pillai et al., 2018).

In a comparison to published Holocene records (Fig. 5), two periods of weak interhemispheric thermal gradient for areas poleward of $30^{\circ} \mathrm{N}$ and $30^{\circ} \mathrm{S}$ occurred on top of more gradual, monotonic changes driven by the seasonality of insolation (Fig. 5e; Marcott et al., 2013; Schneider et al., 2014). These intervals are coeval within the limits of age models with the strong winter monsoon phases in the Arabian Sea (Fig. 5g) and southward swings of the Intertropical Convergence Zone (ITCZ) in the western Atlantic Ocean (Fig. 5f; Haug et al., 2001). Occurring when neoglacial conditions became pervasive across the Northern Hemisphere (Solomina et al., 2015), we identify the two late Holocene periods characterized by a series of low interhemispheric thermal gradient intervals as the early neoglacial anomalies (ENA) between ca. 4500 and 3000 years ago and the late neoglacial anomalies (LNA) after $\sim 1500$, respectively.

LNA includes well-known cold events such as the Little Ice Age (LIA), an episode of global reach but particularly strong in the Northern Hemisphere (IPCC, 2013; Mann et al., 2009; Neukom et al., 2014; PAGES 2k Consortium, 2013) and the preceding cold during the European Migration Period (Büntgen et al., 2016). ENA is more enigmatic at this point. The high resolution Cariaco ITCZ record showing successive southward excursions suggests a series of "LIA-like events" (LIALE in short - a term proposed by Sirocko, 2015). Furthermore, a dominantly negative phase of the North Atlantic Oscillation - NAO (Fig. 5b; Olsen et al., 2012) occurred during ENA, similar to synoptic conditions during LIA. This negative NAO phase was concurrent with moderate increases in storminess in the Greenland Sea, as shown by sea-salt sodium in the GISP2 core (O'Brien et al., 1995) and a cooling of the Iceland Basin and probably the Nordic Seas (Orme et al., 2018). During both ENA and LNA the tropical North

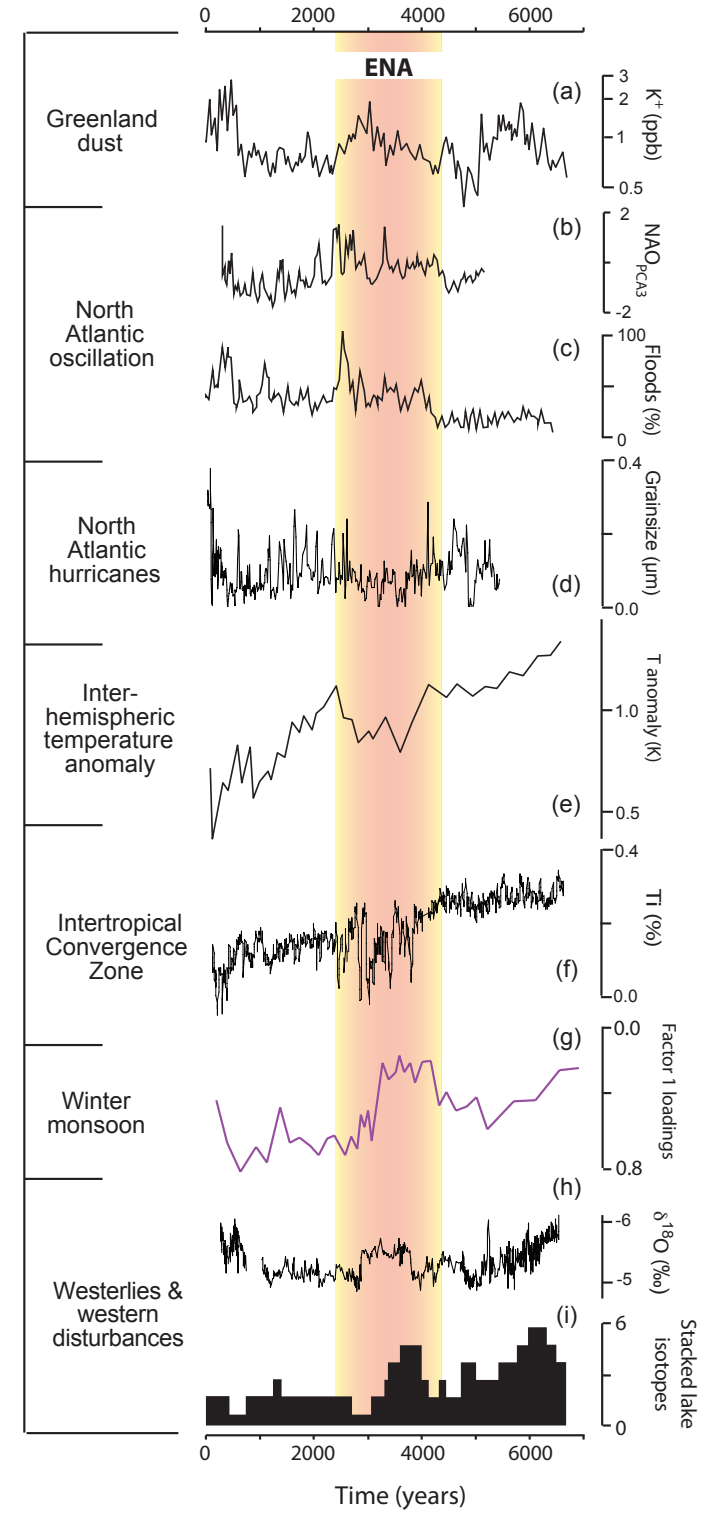

Figure 5. Northern Hemisphere hydroclimatic conditions since the middle Holocene. The period corresponding to the early neoglacial anomalies (ENA) interval is shaded in red hues. From high to low (panels labeled a through i): (a) Greenland dust from non-sea-salt $\mathrm{K}^{+}$showing the strength of the Siberian Anticyclone (O'Brien et al., 1995); (b) NAO proxy reconstruction (Olsen et al., 2012) and (c) negative NAO-indicative floods in the southern Alps (Wirth et al., 2013); (d) grainsize-based hurricane reconstruction in the North Atlantic (van Hengstum et al., 2016); (e) interhemispheric temperature anomaly (Marcott et al., 2013); (f) ITCZ reconstruction at the Cariaco Basin (Haug et al., 2011); (g) winter monsoon ancient DNA-based reconstruction for the northeastern Arabian Sea (this study - in purple); (h) speleothem $\delta^{18} \mathrm{O}$-based precipitation reconstruction for northern Levant (Cheng et al., 2015); and (i) stacked lake isotope records as a proxy precipitation-evaporation regimes over the Middle East and Iran (Roberts et al., 2011). 
Atlantic was remarkably quiescent in terms of hurricane activity (Fig. 5d), which appears to be the direct result of the prevailing southward position of the ITCZ (Donnelly and Woodruff, 2007; van Hengstum et al., 2016).

At mid-latitudes, a southward position for the Westerlies wind belt, as expected during negative NAO conditions, is supported at the western end of our domain of interest by well-defined increases in spring floods in the Southern Alps (Fig. 5c) during both ENA and LNA (Wirth et al., 2013). A higher precipitation-evaporation state in the northern Levant (Fig. 5h; Cheng et al., 2015) and positive balances from lake isotope records in the Eastern Mediterranean (Fig. 5i; Roberts et al., 2011), including lakes in Iran, occur further along the southward Westerlies precipitation belt. The preferential southward track of the Westerlies during ENA and LNA is also in agreement with a stronger Siberian Anticyclone, the dominant mode of winter and spring climate in Eurasia, as interpreted from increases in the GISP2 non-seasalt potassium (Fig. 5a). At the Far East end of the westerly jet, support comes from dust reconstructions in the Sea of Japan (Nagashima et al., 2013) and modeling (Kong et al., 2017), which suggest that the Westerlies stayed preferentially further south in the late Holocene. As in modern climatologies, this suite of paleorecords supports our interpretation that stronger winter monsoon winds during ENA and LNA in the northernmost Arabian Sea, that ought to have driven more convective mixing at our core site, were accompanied by increased precipitation penetration along the Westerlies' path across the Iranian Plateau, Balochistan and Makran to the western Himalayas. Aridification after ca. 4200 years ago in a series of sensitive records from southern East Africa to Australia (Berke et al., 2012; de Boer et al., 2014; Denniston et al., 2013; Li et al., 2018; Russell et al., 2003; Schefuss et al., 2011; Wurtzel et al., 2018) argue for a narrowing of the ITCZ migration belt during ENA within and around the Indian Ocean domain (Li et al., 2018).

In addition to its paleoclimatological value for the Harappan domain (see discussion below), a more fundamental question emerges from our analysis: what triggered ENA and LNA? The reduced influence of insolation on the ITCZ during the late Holocene (e.g., Haug et al., 2001; Schneider et al., 2014) could have provided favorable conditions for internal modes of climate variability, either tropical or polar, to become dominant (e.g., Wanner et al., 2008; Debret et al., 2009; Thirumalai et al., 2018). In order to explain intervals of tropical instabilities that did not extend over the entire Neoglacial various trigger mechanisms and/or coupling intensities between climate subsystems could be invoked. For example, the weaker orbital forcing increased the susceptibility of climate to volcanic and/or solar irradiance, which have been proposed to explain decadal to centennial time events such as the Little Ice Age (e.g., IPCC, 2013; Mann et al., 2009; McGregor et al., 2015; PAGES 2k Consortium. 2013). For the recently defined Late Antique Little Ice Age between 536 to about $660 \mathrm{AD}$, a cluster of volcanic eruptions sustained by ocean and sea-ice feedbacks and a solar minimum have been proposed as triggers (Büntgen et al., 2016). However, during ENA the solar irradiance was unusually stable without prominent minima (Stuiver and Braziunas, 1989; Steinhilber et al., 2012). The volcanic activity in the northern hemisphere was also not particularly higher during ENA than after (Zielenski et al., 1996) and it was matched by an equally active Southern Hemisphere volcanism (Castellano et al., 2005). As previously suggested for the Little Ice Age (Dull et al., 2010; Nevle and Bird, 2008), we speculate that mechanisms related to changes in land cover and possibly land use could have instead been involved in triggering ENA.

Biogeophysical effects of aerosol, albedo and evapotranspiration due to land cover changes were previously shown to be able to modify the position of ITCZ and lead to significant large scale geographic alterations in hydrology (e.g., Chung and Soden, 2017; Dallmeyer et al., 2017; Devaraju et al., 2015; Kang et al., 2018; Sagoo and Storelvmo, 2017; Tierney et al., 2017). Similarly, changes in tropical albedo and concurrent changes in regional atmospheric dust emissions due to aridification during the Neoglacial could have affected the ITCZ. Anthropogenic early land use changes could have also led to large scale biogeophysical impacts (e.g., Smith et al., 2016). Such land-cover- and land-use-driven changes were time-transgressive across Asia and Africa (e.g., Lezine et al., 2017; Jung et al., 2004; Prasad and Enzel, 2006; Shanahan et al., 2015; Tierney et al., 2017; Wang et al., 2010; Kaplan et al., 2011) and could have led to a generalized instability of the global climate as it passed from the warmer Holocene thermal maximum state to the cooler Neoglacial state. Therefore the instability seen during ENA may reflect threshold behavior of the global climate system characterized by fluctuations or flickering (Dakos et al., 2008; Thomas, 2016) or a combination of different mechanisms affecting the coupling intensity between climate subsystems (Wirtz et al., 2010).

\subsection{Climate instability and the Harappan metamorphosis}

In contrast to other urban civilizations of the Bronze Age, such as Egypt and Mesopotamia, Harappans did not employ canal irrigation to cope with the vagaries of river floods despite probable knowledge about this agricultural technology through their western trade network (e.g., Ratnagar, 2004). Instead, they relied on a multiple cropping system that started to develop prior to their urban rise (Madella and Fuller, 2006; Petrie et al., 2017) and integrated the winter crop package imported from the Fertile Crescent (e.g., wheat, barley, peas, lentils) with local summer crops (e.g., millet, sesame, limited rice). A diverse array of cropping practices using inundation and/or dry agriculture that were probably supplemented by labor-intensive well irrigation was employed across the Indus domain, dependent on the regional characteristics of seasonal rains and river floods (e.g., Weber, 2003; Pokharia et al., 2014; Petrie and Bates, 2017; Petrie et al., 2017). The al- 


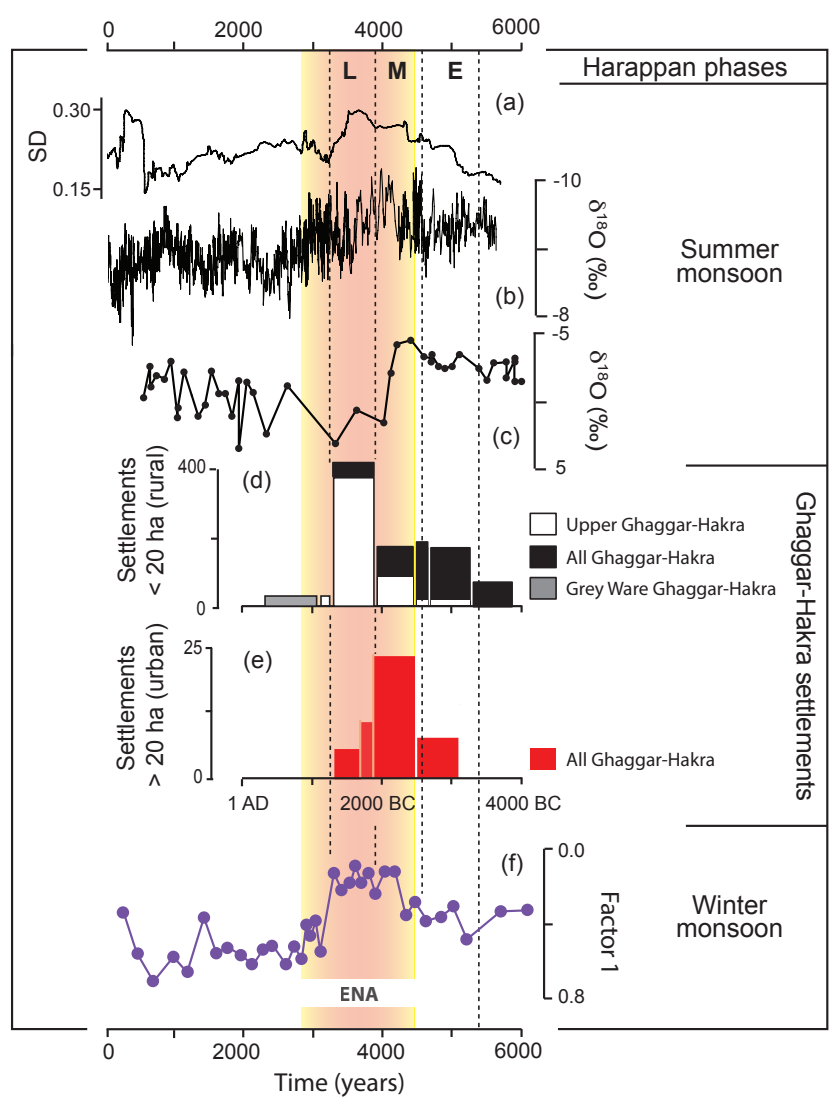

Figure 6. Monsoon hydroclimate changes since the middle Holocene and changes in settlement distribution on the GhaggarHakra interfluve. From high to low (a-f): (a) variability in summer monsoon calculated as 200-year window moving standard deviation of the detrended monsoon record of Katahayat et al. (2017) and (b) the speleothem $\delta^{18} \mathrm{O}$-based summer monsoon reconstruction of Katahayat et al. (2017); (c) lacustrine gastropod $\delta^{18} \mathrm{O}$-based summer monsoon reconstruction (Dixit et al., 2014); (d, e) changes in the number of settlements on the Ghaggar-Hakra interfluve as a function of size and location; and (f) winter monsoon ancient DNAbased reconstruction for the northeastern Arabian Sea (this study in purple). The period corresponding to the early neoglacial anomalies (ENA) is shaded in red hues and durations for Early (E), Mature (M) and Late (L) Harappan phases are shown with dashed lines.

luvial plains adjacent to the foothills of the Himalayas were probably the Harappan region's most amenable to multiple crops using summer monsoon and WD rains directly or redistributed via the perennial and/or ephemeral streams of the G-H interfluve. The orographically controlled stability and availability of multiple water sources that could be used to mitigate climate risks probably made this area more attractive as the inundation agriculture faltered along the Indus and its tributaries when the summer monsoon became more erratic.

Aridity intensified over most of the Indian subcontinent as the summer monsoon rains started to decline after 5000 years ago (Ponton et al., 2012; Prasad et al., 2014). The closest and most detailed summer monsoon reconstruction to the Harappan domain shows a highly variable multicentennial trend to drier conditions between ca. 4300 and 3300 years ago (Fig. 6a and b; Kathayat et al., 2017). Thresholds in evaporation-precipitation affecting lakes on the upper G-H interfluve occurred during the same period (Fig. 6c; Dixit et al., 2014). The flood regime controlled by this variable and declining summer monsoon became more erratic and/or spatially restricted (Giosan et al., 2012; Durcan et al., 2017) making inundation agriculture less dependable. Whether fast or over generations, the bulk of Harappan settlements relocated toward the Himalayan foothills on the plains of the upper G-H interfluve (see Supplement; Possehl, 2002; Kenoyer, 1998; Wright, 2010; Madella and Fuller, 2006; Giosan et al., 2012). Abandoned by Himalayan rivers since the early Holocene (Giosan et al., 2012; Clift et al., 2012; Singh et al., 2017; Dave et al., 2018), this region between the Sutlej and Yamuna was watered by orographically enhanced rain feeding an intricate small river network (e.g., Yashpal et al., 1980; van Dijk et al., 2016; Orengo and Petrie, 2017).

During the aridification process the number of large, urban-sized settlements on the G-H interfluve decreased and the number of small settlements drastically expanded (Fig. 6e and $\mathrm{d}$ respectively). The rivers on the G-H interfluve merged downstream to feed flows along the Hakra into Cholistan, at least seasonally, until the latest Holocene (Giosan et al., 2012; Fig. 2). Regardless if these settlements on the lower G$\mathrm{H}$ interfluve were temporary and mobile (Petrie et al., 2017) most of them were abandoned (Fig. 6d; see also Supplement) as the region aridified, suggesting that flows became less reliable in this region. However, the dense stream network on the upper G-H interfluve must have played an important role in more uniformly watering that region, whether perennially or seasonally. Remarkably, Late Harappan settling did not extend toward the northwest along the entire Himalayan piedmont despite the fact that this region must have received orographically enhanced rains too (Figs. 3 and S1). One possible reason is that interfluves between Indus tributaries (i.e., Sutlej, Beas, Ravi, Chenab, Jhelum; Fig. 2) are not extensive. These Himalayan rivers are entrenched and collect flows inside their wide valleys rather than supporting extensive interfluve stream networks (Giosan et al., 2012).

Our winter monsoon reconstruction suggests that WD precipitation intensified during the time of urban Harappan collapse (Fig. 6f). As the summer monsoon flickered and declined at the same time, the classical push-pull model (e.g., Dorigo and Tobler, 1983; Ravenstein, 1885, 1889) could help explain the Harappan migration. Push-pull factors induce people to migrate from negatively affected regions to more favorable locations. Inundation agriculture along the summer flood-deficient floodplains of the Indus and its tributaries became too risky, which pushed people out, at the same time as the upper G-H region became increasingly attractive due to augmented winter rain, which pulled migrants in. These winter rains would have supported traditional winter crops like 
wheat and barley, while drought tolerant millets could still be grown in rotation during the monsoon season. Diversification toward summer crops took place during the Mature Harappan period, as the winter monsoon steadily increased, beginning around 4500 years ago (Fig. 6f), but a greater reliance on rain crops after the urban collapse implies that intense efforts were made to adapt to hydroclimatic stress at the arid outer edge of the monsoonal rain belt (Giosan et al., 2012; Madella and Fuller, 2006; Petrie and Bates, 2017; Wright et al., 2008). The longevity of the Late Harappan settlements in this region may be due to a consistent availability of multiple year-round sources of water. Summer monsoon remained strong enough locally due to orographic rainfall, while winter precipitation increased during ENA and both these sources provided relief from labor-intensive alternatives such as well irrigation. The decline in the winter monsoon between 3300 and 3000 years ago (Fig. 6) at the end of ENA could have also played a role in the demise of the rural late Harappans during that time as the first Iron Age culture (i.e., the Painted Grey Ware) established itself on the Ghaggar-Hakra interfluve.

The metamorphosis of the Indus civilization remains an episode of great interest. The degradation of cities and disintegration of supra-regional elements of the Indus cultural system such as its script need not be sudden to be defined as a collapse. However, recent contributions of geoarchaeological and settlement patterns studies, together with refinements in chronology, require higher levels of sophistication for addressing links between climatic shifts and cultural decline. While variation in coverage and imprecision in dating sites require further efforts (Petrie et al., 2017), it remains clear that there were shifts in the distribution of population and the range of site sizes, with decline in the size of the largest sites. The impacts of climatic shifts while remarkable from recent chronological correlations (e.g., Katahayat et al., 2017) must now be assessed regionally through a nuanced appreciation of rainfall quantities as well as its seasonality (e.g., Madella and Fuller, 2006; MacDonald, 2011; Petrie et al., 2017; Wright et al., 2008). How precipitation was distributed seasonally would have affected the long-term stability and upstream sources of the stream and river network (Giosan et al., 2012; Singh et al., 2017). Our study suggests broad spatial and temporal patterns of variability for summer and winter precipitation across the Harappan domain but the local hydroclimate aspects, as well as the role of seasonal gluts or shortage of rain on river discharge need also to be considered. For example, did the increase in winter rain during ENA lead to more snow accumulation in the Himalayas that affected the frequency and magnitude of floods along the Indus and its tributaries? Or did settlements in Kutch and Saurashtra, regions of relatively dense habitation during Late Harappan times, also benefit from increases in winter rains despite the fact that modern climatologies suggest scarce local precipitation?

Local reconstructions of seasonal hydroclimatic regimes would greatly enhance our ability to understand social and economic choices made by Harappans. Attempts made to reconstruct WD precipitation in the western Himalayas (e.g., Kotlia et al., 2017) are confounded by the dominant summer monsoon (e.g., Kathayat et al., 2017). Developing local proxies based on summer vs. winter crop remains may provide a more fruitful route for disentangling the sources of water in the Harappan domain (e.g., Bates et al., 2017). The Indus civilization, especially in the northern and eastern regions, had a broad choice of crops of both seasons. Mixed cropping may have become increasingly important, including drought-tolerant, but less productive, summer millets that suited weakening monsoon and winter cereals, including drought-tolerant barley, that were aided by the heightened winter rains of Late Harappan era. Facilitated by this climatic reorganization during ENA, the eastward shift in settlements, while it may have undermined the pre-eminence of the largest urban centers like Harappa, can be seen as a strategic adjustment in subsistence to the summer monsoon decline. Ultimately, ENA is a synoptic pattern that provides a framework to address the role of climate in interacting with social dynamics at a scale larger than the Indus domain. As such, if ENA affected human habitation of the entire eastern Northern Hemisphere, and particularly in the Fertile Crescent and Iran that also depend on winter rains, remains to be assessed.

\section{Conclusions}

To assess the role of winter precipitation in Harappan history, we reconstructed the Indian winter monsoon over the last 6000 years using paleobiological records from the Arabian Sea. According to modern climatologies, strong winter monsoon winds correspond to rains along a zonal swath extending through the western Himalayas. Changes in the planktonic community structure indicative of cool, productive waters highlight strong winter monsoon conditions between ca. 4500 and 3000 years ago, an interval spanning the transition from peak development of the urban Harappan to the demise of its last rural elements. Inferred increases in winter rains during this time were contemporaneous with the regionally documented decline in summer monsoon, which has previously been interpreted as detrimental to the inundation agriculture practiced along the Indus and its tributaries. We propose that the combined changes in summer and winter monsoon hydroclimate triggered the metamorphosis of the urban Harappan civilization into a rural society. A push-pull migration can better explain the relocation of Harappans from summer flood-deficient river valleys to the Himalayan piedmont plains with augmented winter rains and a greater reliance on rainfed crops. Two seasons of cultivation helped to spread risk and enhance sustainability. Summer and winter orographic precipitation above and across the piedmont plains fed a dense stream network supporting agriculture close to another millennium for the rural late Harappans. 
Previous reconstructions and our new monsoon record, in concert with other paleoclimate series from the Northern Hemisphere and tropics, display two late Holocene periods of generalized climate instability: ENA between ca. 4500 and 3000 years ago and LNA after $\sim 1500$ years ago. The reduced influence of insolation during the late Holocene could have provided favorable conditions for internal modes of climate variability, either tropical or polar, to become dominant and lead to such instability intervals. Both ENA and LNA occurred during low interhemispheric thermal gradients and dominantly negative phases of NAO characterized by more southward swings of both the ITCZ and Westerlies belt at mid-northern latitudes, reduced hurricane activity and increases in high-latitude storminess in the Atlantic. The preferential southward track of the Westerlies during ENA and LNA is supported by increased rains from WDs from the Levant into Iran and Balochistan, but a stronger Siberian Anticyclone and weaker winds along the northern westerly track as far east as the Sea of Japan. Susceptibility of climate to volcanic, solar irradiance and/or land cover were proposed to explain LNA but we speculate that timetransgressive changes in land cover across Asia and Africa could have been involved in triggering ENA as it passed from the warmer Holocene thermal maximum state to the cooler Neoglacial state.

During the review of our manuscript, a paper on a similar topic was accepted for discussion in this journal (Giesche et al., 2018). The authors comment on our work and we provide a brief reply herein. Giesche et al. (2018) used multi-species planktonic foraminifer $\delta^{18} \mathrm{O}$ and $\delta^{13} \mathrm{C}$ from a core close to our site to infer a history of the Indian winter monsoon between 4.5 and $3.0 \mathrm{kaBP}$ that is different than what we propose. We suggest that the ancient DNA and \% Globigerina falconensis proxies are better suited to reconstruct monsoon changes by providing the right balance between planktonic whole-ecosystem change and proxy specificity, respectively.

Data availability. Data presented in the paper can be accessed in the Supplement. After publication the data will also be uploaded to the Woods Hole Open Access Server (FAIR-aligned data repository). 
Appendix A: Climate variability and the Indus Civilization

The Harappan or Indus Valley Civilization developed on the Indus alluvial plain and adjacent regions (Figs. 1 and 2). Between the Indus and Ganges watersheds, a now largely defunct smaller drainage system, the Ghaggar-Hakra, was also heavily populated. The Harappan cultural tradition (Kenoyer, 1998; Possehl, 2002; Wright, 2010) evolved during the Early Phase (ca. 5200-4500 years ago) from antecedent agricultural communities of the hills bordering the Indus plain to the west and reached its urban peak (Mature Phase) between ca. 4500 and 3900 years ago. The Harappans were agrarian but developed large, architecturally complex urban centers and a sophisticated material culture coupled with a robust trade system. In contrast to the neighboring hydraulic civilizations of Mesopotamia and Egypt, Harappans appear to have invested less effort to control water resources by largescale canal irrigation near cities but relied primarily on fluvial inundation for winter crops and additionally on rain for summer crops. Deurbanization ensued after approximately 3900 years ago and was characterized by the development of increasingly regional artefact styles and trading networks, as well as the disappearance of the distinctive Harappan script. Some settlements exhibited continuity, albeit with reduced size, whereas many riverine sites were abandoned, in particular along the Indus and its tributaries. Between ca. 3900 and 3200 years ago, there was a proliferation of smaller, villagetype settlements, especially on the Ghaggar-Hakra interfluve. Socio-economic as well as environmental hypotheses have been invoked to explain the collapse of urban Harappan society, including foreign invasions, social instabilities, trade decline, climate deterioration, fluvial dynamics and humaninduced environmental degradation.

The "climate-culture hypothesis", first clearly articulated by Singh (1971) and Singh et al. (1990) based on pollen records from Rajasthan lakes, argues for climate variability at the vulnerable arid outer edge of the monsoonal rain belt as a determining factor in Harappan cultural transformations (Figs. 1, 2 and S4). These reconstructions together with other early paleoclimate forays in Rajasthan (see review of Madella and Fuller, 2006) proposed that enhanced summer monsoon rains assisted the development of the urban Harappan but weakening monsoon conditions after 42003800 years ago contributed to its collapse. In marine sediments, planktonic oxygen isotope records in a core from the Makran continental margin were interpreted to suggest a reduction in the Indus river discharge ca. 4200 years ago (Staubwasser et al., 2003). More recent work, proximal to the Harappan heartland, provides strong support for this "climate-culture hypothesis" while emphasizing the complexity of both spatiotemporal hydroclimate pattern and Harappan cultural responses. Paleohydrological records from lakes in northern Rajasthan and Haryana show wetter conditions prevailing during the Early Harappan phase, provid- ing favorable climate conditions for urbanization (Dixit et al., 2018) and a distinct weakening of summer monsoon around 4100 years ago (Fig. 6c; Dixit et al., 2014). Another summer monsoon reconstruction from Sahiya cave above the Himalayan piedmont (Fig. 6a and b; Kathayat et al., 2017) shows a pluvial optimum during most of the urban phase followed by drying after 4100 years ago. This high resolution speleothem-based reconstruction also reveals that the multicentennial trend to drier conditions between ca. 4100 and 3200 years ago was in fact highly variable at centennial scales.

Studies of fluvial dynamics on the Harappan territory are consistent with a dry late Holocene affecting the Harappan way of life. Landscape semi-fossilization along the Indus and its tributaries suggest that floods became erratic and less extensive making inundation agriculture unsustainable for the post-urban Harappans (Giosan et al., 2012). In contrast to Himalayan tributaries of the Indus, which incised their alluvial deposits in early-mid-Holocene, the lack of wide entrenched valleys on the Ghaggar-Hakra interfluve indicates that large, glacier-fed rivers did not flow across this region during Harappan times. Geochemical fingerprinting of fluvial deposits on the lower and upper Ghaggar-Hakra interfluve (Clift et al., 2012 and Dave et al., 2018 respectively) showed that the capture of the Yamuna to the Ganges basin occurred prior to the Holocene. Similarly, abandonment and infilling of a large paleochannel demonstrates that the Sutlej River relocated to its present course away from the GhaggarHakra interfluve by 8,000 years ago, well before Harappan established themselves in the region (Singh et al., 2017). However, widespread fluvial redistribution of sediment from the upper Ghaggar-Hakra interfluve (e.g., Saini et al., 2009; Singh et al., 2018) all the way down to the lower Hakra (Clift et al., 2012) and toward the Nara valley (Giosan et al., 2012) suggests that monsoon rains were able to sustain smaller streams through that time, but as the monsoon weakened, rivers gradually dried or became seasonal, affecting habitability along their course.

If the climatic trigger for the urban Harappan collapse was probably the decline of the summer monsoon, the agricultural Harappan economy showed a large degree of adaptation to water availability. The long-lived survival of Late Harappan cultures until ca. 3200 years ago under a drier climate and less active fluvial network is the subject of the present study and further ongoing efforts (e.g., Kotlia et al., 2017; Petrie et al., 2017) that seek to understand the variability in hydroclimate and moisture sources across the Indus domain and how these relate to agricultural adaptations. 
Supplement. The supplement related to this article is available online at: https://doi.org/10.5194/cp-14-1669-2018-supplement.

Author contributions. LG and PDC collected the core. MC and $\mathrm{CW}$ measured and interpreted ancient DNA. AGD performed factor analysis. KT provided climatology. LG, WDO, MC, KT and DQF interpreted the results with input from all authors. LG wrote the manuscript with input from all authors.

Competing interests. The authors declare that they have no conflict of interest.

Acknowledgements. This work was supported by the NSF OCE grant no. 0634731 and internal WHOI funds to Liviu Giosan, NSF MGG grant no. 1357017 to Marco J. L. Coolen, Valier Galy and Liviu Giosan; and a C-DEBI grant no. OCE-0939564 to William D. Orsi. We thank the editor and reviewers for suggestions that improved the original manuscript. Thanks go to the staff of the British Ocean Sediment Core Research Facility for help with sampling, to Mary Carman, for help with foraminifera, Lloyd Keigwin for discussions and our Pakistani and Indian colleagues who helped with acquiring and/or provided access to data including Kavita Gangal, Ronojoy Adhikari, Ali Tabrez and Asif Inam.

Edited by: Hans Linderholm

Reviewed by: Fredrik Charpentier Ljungqvist and two anonymous referees

\section{References}

Altabet, M. A., Francois, R., Murray, D. W., and Prell, W. L.: Climate-related variations in denitrification in the Arabian Sea from sediment 15N/14N ratios, Nature, 373, 506-509, 1995.

Arbuszewski, J. A., deMenocal, P. B., Cleroux, C., Bradtmiller, L., and Mix, A.: Meridional shifts of the Atlantic intertropical convergence zone since the Last Glacial Maximum, Nat. Geosci., 6, 959-962, 2013.

Banse, K., and McClain, C. R.: Winter blooms of phytoplankton in the Arabian Sea as observed by the Coastal Zone Color Scanner, Mar. Ecol. Progr. Series, 34, 201-211, 1986.

Bates, J., Singh, R. N., and Petrie, C. A.: Exploring Indus crop processing: combining phytolith and macrobotanical analyses to consider the organisation of agriculture in northwest India c. 3200-1500 BC, Veg. Hist. Archaeobot., 26, 25-41, 2017.

Berger, W. H. and Loutre M. F.: Insolation values for the climate of the last 10 m. y., Quaternary Sci. Rev., 10, 297-317, 1991.

Berke, M. A., Johnson, T. C., Werne, J. P., Grice, K., Schouten, S., and Damsté, J. S. S.: Molecular records of climate variability and vegetation response since the Late Pleistocene in the Lake Victoria basin, East Africa, Quaternary Sci. Rev., 55, 59-74, 2012.

Böll, A., Lückge, A., Munz, P., Forke, S., Schulz, H., Ramaswamy, V., Rixen, T., Gaye, B., and Emeis, K. C.: Late Holocene primary productivity and sea surface temperature variations in the northeastern Arabian Sea: Implications for winter monsoon variability, Paleoceanography, 29, 778-794, 2014.
Bookhagen, B. and Burbank, D. W.: Towards a complete Himalayan hydrological budget: the spatiotemporal distribution of snow melt and rainfall and their impact on river discharge, J. Geophys. Res.-Earth, 115, 1-25, 2010.

Boos, W. R. and Korty, R. L.: Regional energy budget control of the intertropical convergence zone and application to mid-Holocene rainfall, Nat. Geosci., 9, 892-897, 2016.

Broccoli, A. J., Dahl, K. A., and Stouffer, R. J.: Response of the ITCZ to Northern Hemisphere cooling, Geophys. Res. Lett., 33, L01702, https://doi.org/10.1029/2005GL024546, 2006.

Broecker, W. S. and Putnam, A. E.: Hydrologic impacts of past shifts of Earth's thermal equator offer insight into those to be produced by fossil fuel $\mathrm{CO}_{2}$, P. Natl. Acad. Sci. USA, 110, 16710 16715, 2013.

Brooke, J. L.: Climate Change and the Course of Global History: A Rough Journey, Cambridge University Press, Cambridge, 2014.

Büntgen, U., Myglan, V. S., Ljungqvist, F. C., McCormick, M., Di Cosmo, N., Sigl, M., Jungclaus, J., Wagner, S., Krusic, P. J., Esper, J., and Kaplan, J. O.: Cooling and societal change during the Late Antique Little Ice Age from 536 to around 660 AD, Nat. Geosci., 9, 231-236, 2016.

Butzer, K. W.: Collapse, environment, and society, P. Natl. Acad. Sci. USA, 109, 3632-3639, 2012.

Camoin, G. F., Montaggioni, L. F., and Braithwaite, C. J. R.: Late glacial to post glacial sea levels in the western Indian Ocean, Mar. Geol., 206, 119-146, 2004.

Caporaso, J. G., Kuczynski, J., Stombaugh, J., Bittinger, K., Bushman, F. D., Costello, E. K., Fierer, N., Pena, A. G., Goodrich, J. K., Gordon, J. I., Huttley, G. A, Kelley, S. T., Knights, D., Koenig, J. E., Ley, R. E., Lozupone, C. A., McDonald, D., Muegge, B. D., Pirrung, M., Reeder, J., Sevinsky, J. R., Turnbaugh, P. T., Walters, W. A., Widmann, J., Yatsunenko, T., Zaneveld, J., and Knight, R.: QIIME allows analysis of highthroughput community sequencing data, Nat. Methods 7, 335336, 2010.

Carey, M.: Climate and history: a critical review of historical climatology and climate change historiography, Wiley Interdiscip. Rev. Clim. Change, 3, 233-249, 2012.

Castellano, E., Becagli, S., Hansson, M., Hutterli, M., Petit, J. R., Rampino, M. R., Severi, M., Steffensen, J. P., Traversi, R., and Udisti, R.: Holocene volcanic history as recorded in the sulphate stratigraphy of the European Project for Ice Coring in Antarctica Dome C (EDC96) ice core, J. Geophys. Res.-Atmos., 110, D6, https://doi.org/10.1029/2004JD005259, 2005.

Cheng, H., Sinha, A., Verheyden, S., Nader, F. H., Li, X. L., Zhang, P. Z., Yin, J. J., Yi, L., Peng, Y. B., Rao, Z. G., and Ning, Y. F.: The climate variability in northern Levant over the past 20,000 years, Geophys. Res. Lett., 42, 8641-8650, 2015.

Chiang, J. C. H. and Bitz, C. M.: Influence of high latitude ice cover on the marine Intertropical Convergence Zone, Clim. Dynam., 25, 477-496, 2005.

Chung, E. S. and Soden, B. J.: Hemispheric climate shifts driven by anthropogenic aerosol-cloud interactions, Nat. Geosci., 10, 566-571, 2017.

Clift, P. D., Carter, A., Giosan, L., Durcan, J., Duller, G. A., Macklin, M. G., Alizai, A., Tabrez, A. R., Danish, M., VanLaningham, S., and Fuller, D. Q.: U-Pb zircon dating evidence for a Pleistocene Sarasvati River and Capture of the Yamuna River, Geology, 40, 211-214, 2012. 
Clift, P. D., Giosan, L., Henstock, T. J., and Tabrez, A. R.: Sediment storage and reworking on the shelf and in the Canyon of the Indus River-Fan System since the Last Glacial Maximum, Basin Res., 26, 183-202, 2014.

Coolen, M. J., Orsi, W. D., Balkema, C., Quince, C., Harris, K., Sylva, S. P., Filipova-Marinova, M., and Giosan, L.: Evolution of the plankton paleome in the Black Sea from the Deglacial to Anthropocene, P. Natl. Acad. Sci. USA, 110, 8609-8614, 2013.

Cortese, G. and Abelmann, A.: Radiolarian-based paleotemperatures during the last $160 \mathrm{kyr}$ at ODP Site 1089 (Southern Ocean, Atlantic Sector), Palaeogeogr. Palaeocl., 182, 259-286, 2002.

Curry, W. B., Ostermann, D. R., Guptha, M. V. S., and Ittekkot, V.: Foraminiferal production and monsoonal upwelling in the Arabian Sea: evidence from sediment traps, Geological Society, London, Spec. Pub., 64, 93-106, 1992.

Dakos, V., Scheffer, M., van Nes, E. H., Brovkin, V., Petoukhov, V., and Held, H.: Slowing down as an early warning signal for abrupt climate change, P. Natl. Acad. Sci. USA, 105, 1430814312, 2008.

Dallmeyer, A., Claussen, M., Ni, J., Cao, X., Wang, Y., Fischer, N., Pfeiffer, M., Jin, L., Khon, V., Wagner, S., Haberkorn, K., and Herzschuh, U.: Biome changes in Asia since the mid-Holocene - an analysis of different transient Earth system model simulations, Clim. Past, 13, 107-134, https://doi.org/10.5194/cp-13107-2017, 2017.

d'Alpoim Guedes, J. A. D. A., Crabtree, S. A., Bocinsky, R. K., and Kohler, T. A.: Twenty-first century approaches to ancient problems: Climate and society, P. Natl. Acad. Sci. USA, 113, 1448314491, 2016.

Dave, A. K., Courty, M. A., Fitzsimmons, K. E., and Singhvi, A. K.: Revisiting the contemporaneity of a mighty river and the Harappans: Archaeological, stratigraphic and chronometric constraints, Quat. Geochron., in preparation, 2018.

de Boer, E. J. D., Tjallingii, R., Vélez, M. I., Rijsdijk, K. F., Vlug, A., Reichart, G. J., Prendergast, A. L., Louw, P. G. B. D., Florens, F. B. V., and Baider, C.: Climate variability in the SW Indian Ocean from an 8000-yr long multi-proxy record in the Mauritian lowlands shows a middle to late Holocene shift from negative IOD-state to ENSO-state, Quaternary Sci. Rev., 86, 175189, 2014.

Debret, M., Sebag, D., Crosta, X., Massei, N., Petit, J. R., Chapron, E., and Bout-Roumazeilles, V.: Evidence from wavelet analysis for a mid-Holocene transition in global climate forcing, Quaternary Sci. Rev., 28, 2675-2688, 2009.

deMenocal, P. B.: Cultural responses to climate change during the late Holocene, Science, 292, 667-673, 2001.

Denniston, R. F., Wyrwoll, K. H., Polyak, V. J., Brown, J. R., Asmerom, Y., Wanamaker Jr., A. D., Lapointe, Z., Ellerbroek, R., Barthelmes, M., and Cleary, D.: A Stalagmite record of Holocene Indonesian-Australian summer monsoon variability from the Australian tropics, Quaternary Sci. Rev., 78, 155-168, 2013.

Devaraju, N., Govindasamy, B., and Angshuman, M.: Effects of large-scale deforestation on precipitation in the monsoon regions: Remote versus local effects, P. Natl. Acad. Sci. India, 112, 3257-3262, 2015.

Dimri, A. P.: Surface and upper air fields during extreme winter precipitation over the western Himalayas, Pure Appl. Geophys., 163, 1679-1698, 2006.
Dimri, A. P., Niyogi, D., Barros, A. P., Ridley, J., Mohanty, U. C., Yasunari, T., and Sikka, D. R.: Western disturbances: a review, Rev. Geophys., 53, 225-246, 2015.

Dixit, Y., Hodell, D. A., and Petrie, C. A.: Abrupt weakening of the summer monsoon in northwest India $\sim 4100 \mathrm{yr}$ ago, Geology, 42, 339-342, 2014.

Dixit, Y., Hodell, D. A., Giesche, A., Tandon, S. K., Gázquez, F., Saini, H. S., Skinner, L. C., Mujtaba, S. A. I., Pawar, V., Singh, R. N., and Petrie, C. A.: Intensified summer monsoon and the urbanization of Indus Civilization in northwest India, Sci. Rep., 8, 4225, https://doi.org/10.1038/s41598-018-22504-5, 2018.

Donges, J. F., Donner, R. V., Marwan, N., Breitenbach, S. F. M., Rehfeld, K., and Kurths, J.: Non-linear regime shifts in Holocene Asian monsoon variability: potential impacts on cultural change and migratory patterns, Clim. Past, 11, 709-741, https://doi.org/10.5194/cp-11-709-2015, 2015.

Donnelly, J. P. and Woodruff, J. D.: Intense hurricane activity over the past 5,000 years controlled by El Niño and the West African monsoon, Nature, 447, 465-468, 2007.

Doose-Rolinski, H., Rogalla, U., Scheeder, G., Lückge, A., and Rad, U.: High-resolution temperature and evaporation changes during the late Holocene in the northeastern Arabian Sea, Paleoceanography, 16, 358-367, 2001.

Dorigo, G. and Tobler, W.: Push-pull migration laws, Ann. Assoc. Am. Geogr., 73, 1-17, 1983.

Dull, R. A., Nevle, R. J., Woods, W. I., Bird, D. K., Avnery, S., and Denevan, W. M.: The Columbian encounter and the Little Ice Age: Abrupt land use change, fire, and greenhouse forcing, Ann. Assoc. Am. Geogr., 100, 755-771, 2010.

Durcan, J. A., Thomas, D. S., Gupta, S., Pawar, V., Singh, R. N., and Petrie, C. A.: Holocene landscape dynamics in the GhaggarHakra palaeochannel region at the northern edge of the Thar Desert, northwest India, Quat. Int., in preparation, 2017.

Edgar, R. C.: Search and clustering orders of magnitude faster than BLAST, Bioinformatics, 26, 2460-2461, 2010.

Fleitmann, D., Burns, S. J., Mudelsee, M., Neff, U., Kramers, J., Mangini, A., and Matter, A.: Holocene forcing of the Indian monsoon recorded in a stalagmite from southern Oman, Science, 300, 1737-1739, 2003.

Fuller, D. Q.: Finding plant domestication in the Indian subcontinent, Curr. Anthropol., 52, 347-362, 2011.

Gangal, K., Vahia, M., and Adhikari, R.: Spatio-temporal analysis of the Indus urbanization, Curr. Sci. India, 98, 846-852, 2010.

Giesche, A., Staubwasser, M., Petrie, C. A., and Hodell, D. A.: Re-examining the $4.2 \mathrm{ka} \mathrm{BP}$ event in foraminifer isotope records from the Indus River delta in the Arabian Sea, Clim. Past Discuss., https://doi.org/10.5194/cp-2018-104, in review, 2018.

Giosan, L., Clift, P. D., Macklin, M. G., Fuller, D. Q., Constantinescu, S., Durcan, J. A., Stevens, T., Duller, G. A. T., Tabrez, A., Adhikari, R., Gangal, K., Alizai, A., Filip, F., VanLaningham, S., and Syvitski, J. P. M.: Fluvial Landscapes of the Harappan Civilization, P. Natl. Acad. Sci. USA, 109, 1688-1694, 2012.

Haldon, J., Mordechai, L., Newfield, T. P., Chase, A. F., Izdebski, A., Guzowski, P., Labuhn, I., and Roberts, N.: History meets palaeoscience: Consilience and collaboration in studying past societal responses to environmental change, P. Natl. Acad. Sci. USA, 115, 201716912, DOI:10.1073/pnas.1716912115, 2018. 
Haug, G. H., Hughen, K. A., Sigman, D. M., Peterson, L. C., and Rohl, U.: Southward migration of the Intertropical Convergence Zone through the Holocene, Science, 293, 1304-1308, 2001.

Huffman, G. J., Bolvin, D. T., Nelkin, E. J., Wolff, D. B., Adler, R. F., Gu, G., Hong, Y., Bowman, K. P., and Stocker, E. F.: The TRMM multisatellite precipitation analysis (TMPA): Quasiglobal, multiyear, combined-sensor precipitation estimates at fine scales, J. Hydrometeo., 8, 38-55, 2007.

IPCC Climate Change 2013: The Physical Science Basis, edited by: Stocker, T. F. et al., Cambridge University Press, Cambridge, 2013.

Ivory, S. J. and Lézine, A. M.: Climate and environmental change at the end of the Holocene Humid Period: A pollen record off Pakistan, Comptes Rendus Geosci., 341, 760-769, 2009.

Izdebski, A., Holmgren, K., Weiberg, E., Stocker, S. R., Buentgen, U., Florenzano, A., Gogou, A., Leroy, S. A., Luterbacher, J., Martrat, B., and Masi, A.: Realising consilience: how better communication between archaeologists, historians and geoscientists can transform the study of past climate change in the Mediterranean, Quaternary Sci. Rev., 136, 5-22, 2016.

Jia, G., Bai, Y., Yang, X., Xie, L., Wei, G., Ouyang, T., Chu, G., Liu, Z., and Peng, P. A.: Biogeochemical evidence of Holocene East Asian summer and winter monsoon variability from a tropical maar lake in southern China, Quaternary Sci. Rev., 111, 51-61, 2015

Jung, S. J. A., Davies, G. R., Ganssen, G. M., and Kroon, D.: Stepwise Holocene aridification in NE Africa deduced from dustborne radiogenic isotope records, Earth Planet. Sc. Lett., 221, 27-37, 2004.

Kamikuri, S. I., Motoyama, I., and Nishimura, A.: Radiolarian assemblages in surface sediments along longitude $175 \mathrm{E}$ in the Pacific Ocean, Mar. Micropaleontol., 69, 151-172, 2008.

Kang, S. M., Shin, Y., and Xie, S. P.: Extratropical forcing and tropical rainfall distribution: energetics framework and ocean Ekman advection, npj Clim. Atmos. Sci., 1, 20172, https://doi.org/10.1038/s41612-017-0004-6, 2018.

Kaplan, J. O., Krumhardt, K. M., Ellis, E. C., Ruddiman, W. F., Lemmen, C., and Goldewijk, K. K.: Holocene carbon emissions as a result of anthropogenic land cover change, Holocene, 21, 775-791, 2011.

Karim, A. and Veizer, J.: Water balance of the Indus river basin and moisture source in the Karakoram and western Himalayas: implications from hydrogen and oxygen isotopes river water, J. Geophys. Res. 107, 4362, https://doi.org/10.1029/2000JD000253, 2002.

Kathayat, G., Cheng, H., Sinha, A., Yi, L., Li, X., Zhang, H., Li, H., Ning, Y., and Edwards, R. L.: The Indian monsoon variability and civilization changes in the Indian subcontinent, Sci. Adv., 3, p.e1701296, https://doi.org/10.1126/sciadv.1701296, 2017.

Kenoyer, J. M.: Ancient Cities of the Indus Valley Civilization, Oxford University Press, Oxford, 1998.

Kong, W., Swenson, L. M., and Chiang, J. C.: Seasonal transitions and the westerly jet in the Holocene East Asian summer monsoon, J. Climate, 30, 3343-3365, 2017.

Kotlia, B. S., Singh, A. K., Joshi, L. M., and Bisht, K.: Precipitation variability over Northwest Himalaya from $\sim 4.0$ to $1.9 \mathrm{ka} \mathrm{BP}$ with likely impact on civilization in the foreland areas, J. Asian Earth Sci., 162, 148-159, 2017.
Kumar, M.: Linguistics, Archaeology and the Human Past, Occasional Paper 7, edited by: Osada, T. and Uesugi, A., Research Institute for Humanity and Nature, Nakanishi Printing Co. Ltd., Kyoto, 1-75, 2009.

Lézine, A. M., Ivory, S. J., Braconnot, P., and Marti, O.: Timing of the southward retreat of the ITCZ at the end of the Holocene Humid Period in Southern Arabia: Data-model comparison, Quaternary Sci. Rev., 164, 68-76, 2017.

Li, H., Cheng, H., Sinha, A., Kathayat, G., Spötl, C., André, A. A., Meunier, A., Biswas, J., Duan, P., Ning, Y., and Edwards, R. L.: Speleothem Evidence for Megadroughts in the SW Indian Ocean during the Late Holocene, Clim. Past Discuss., https://doi.org/10.5194/cp-2018-100, in review, 2018.

Li, Y. and Morrill, C.: A Holocene East Asian winter monsoon record at the southern edge of the Gobi Desert and its comparison with a transient simulation, Clim. Dynam. 45, 1219-1234, 2015.

Lückge, A., Doose-Rolinski, H., Khan, A. A., Schulz, H., and Von Rad, U.: Monsoonal variability in the northeastern Arabian Sea during the past 5000 years: geochemical evidence from laminated sediments, Palaeogeogr. Palaeocl., 167, 273-286, 2001.

Luis, A. J. and Kawamura, H.: Air-sea interaction, coastal circulation and primary production in the eastern Arabian Sea: a review, J. Oceanogr., 60, 205-218, 2004.

Ljungqvist, F. C.: Issues and Concepts in Historical Ecology: The Past and Future of Landscapes and Regions, in: Issues and Concepts in Historical Ecology: If the Past Teaches, What Does the Future Learn?, edited by: Crumley, C. L. et al., Cambridge University Press, Cambridge, 41-83, 2017.

MacDonald, G.: Potential influence of the Pacific Ocean on the Indian summer monsoon and Harappan decline, Quat. Int., 229, 140-148, 2011.

Madella, M. and Fuller, D. Q.: Palaeoecology and the Harappan Civilisation of South Asia: a reconsideration, Quaternary Sci. Rev., 25, 1283-1301, 2006.

Madhupratap, M., Kumar, S. P., Bhattathiri, P. M. A., Kumar, M. D., Raghukumar, S., Nair, K. K. C., and Ramaiah, N.: Mechanism of the biological response to winter cooling in the northeastern Arabian Sea, Nature, 384, 549-552, 1996.

Mallah, Q. H.: Current Studies on the Indus Civilization RohnManohar Indus Project Series, edited by: Osada, T. and Uesugi, A., Manohar Publishers, India, 27-76, 2010.

Mann, M. E., Zhang, Z., Rutherford, S., Bradley, R. S., Hughes, M. K., Shindell, D., Ammann, C., Faluvegi, G., and Ni, F.: Global signatures and dynamical origins of the Little Ice Age and Medieval Climate Anomaly, Science, 326, 1256-1260, 2009.

Marcott, S. A., Shakun, J. D., Clark, P. U., and Mix, A. C.: A reconstruction of regional and global temperature for the past 11,300 years, Science, 339, 1198-1201, 2013.

McGee, D., Donohoe, A., Marshall, J., and Ferreira, D.: Changes in ITCZ location and cross-equatorial heat transport at the Last Glacial Maximum, Heinrich Stadial 1, and the mid-Holocene, Earth Planet. Sc. Lett., 390, 69-79, 2014.

McGregor, H. V., Evans, M. N., Goosse, H., Leduc, G., Martrat, B., Addison, J. A., Mortyn, P. G., Oppo, D. W., Seidenkrantz, M. S., Sicre, M. A., and Phipps, S. J.: Robust global ocean cooling trend for the pre-industrial Common Era, Nat. Geosci., 8, 671677, 2015. 
Meadow, R. H.: Harappa excavations 1986-1990: a multidisciplinary approach to Third Millenium urbanism, Prehistory Press, 275 pp., 1991.

McMichael, A. J.: Insights from past millennia into climatic impacts on human health and survival, P. Natl. Acad. Sci. USA, 10, 47304737, 2012.

Mughal, M. R.: Pakistan Archaeology, 29, edited by: Iqbal, F., Khan, M. A., and Hassan, M., Department of Archaeology and Museums, Pakistan, Karachi, 1996.

Mughal, M. R.: Ancient Cholistan: archaeology and architecture, Ferozsons Press, 1997.

Munz, P. M., Siccha, M., Lückge, A., Böll, A., Kucera, M., and Schulz, H.: Decadal-resolution record of winter monsoon intensity over the last two millennia from planktic foraminiferal assemblages in the northeastern Arabian Sea, Holocene, 25, 17561771, 2015.

Nagashima, K., Tada, R., and Toyoda, S.: Westerly jet-East Asian summer monsoon connection during the Holocene, Geochem. Geophys. Geosyst., 14, 5041-5053, 2013.

Nelson, M. C., Ingram, S. E., Dugmore, A. J., Streeter, R., Peeples, M. A., McGovern, T. H., Hegmon, M., Arneborg, J., Kintigh, K. W., Brewington, S., and Spielmann, K. A.: Climate challenges, vulnerabilities, and food security, P. Natl. Acad. Sci. USA, 113, 298-303, 2016.

Neukom, R., Gergis, J., Karoly, D. J., Wanner, H., Curran, M., Elbert, J., González-Rouco, F., Linsley, B. K., Moy, A. D., Mundo, I., and Raible, C. C.: Inter-hemispheric temperature variability over the past millennium, Nat. Clim. Change, 4, 362-367, 2014.

Nevle, R. J. and Bird, D. K.: Effects of syn-pandemic fire reduction and reforestation in the tropical Americas on atmospheric $\mathrm{CO}_{2}$ during European conquest, Palaeogeogr. Palaeocl., 264, 25-38, 2008.

O’Brien, S. R., Mayewski, P. A., Meeker, L. D., Meese, D. A., Twickler, M. S., and Whitlow, S. I.: Complexity of Holocene climate as reconstructed from a Greenland ice core, Science, 270, 1962-1964, 1995.

Olsen, J., Anderson, N. J., and Knudsen, M. F.: Variability of the North Atlantic Oscillation over the past 5,200 years, Nat. Geosci., 5, 808-812, 2012.

Orme, L. C., Miettinen, A., Divine, D., Husum, K., Pearce, C., Van Nieuwenhove, N., Born, A., Mohan, R., and Seidenkrantz, M. S.: Subpolar North Atlantic sea surface temperature since 6 ka BP: Indications of anomalous ocean-atmosphere interactions at 4-2 ka BP, Quaternary Sci. Rev., 194, 128-142, 2018.

Orsi, W. D., Smith, J. M., Wilcox, H. M., Swalwell, J. E., Carini, P., Worden, A. Z., and Santoro, A. E.: Ecophysiology of uncultivated marine euryarchaea is linked to particulate organic matter, ISME J., 9, 1747-1763, 2015.

Orsi, W. D., Coolen, M. J., Wuchter, C., He, L., More, K. D., Irigoien, X., Chust, G., Johnson, C., Hemingway, J. D., Lee, M., Galy, V., and Giosan, L.: Climate oscillations reflected within the microbiome of Arabian Sea sediments, Sci. Rep., 7, 6040, https://doi.org/10.1038/s41598-017-05590-9, 2017.

Orengo, H. A. and Petrie, C. A.: Large-scale, multi-temporal remote sensing of palaeo-river networks: a case study from northwest India and its implications for the Indus civilisation, Remote Sens., 9, 735, https://doi.org/10.3390/rs9070735, 2017.

PAGES 2k Consortium: Continental-scale temperature variability during the past two millennia, Nat. Geosci., 6, 339-346, 2013.
Petrie, C. A. and Bates, J.: 'Multi-cropping', Intercropping and Adaptation to Variable Environments in Indus South Asia, J. World Prehist., 30, 81-130, 2017.

Petrie, C. A., Singh, R. N., Bates, J., Dixit, Y., French, C. A., Hodell, D. A., Jones, P. J., Lancelotti, C., Lynam, F., Neogi, S., and Pandey, A. K.: Adaptation to Variable Environments, Resilience to Climate Change: Investigating Land, Water and Settlement in Indus Northwest India, Curr. Anthrop., 58, 1-30, 2017.

Pisias, N. G., Murray, R. W., and Scudder, R. P.: Multivariate statistical analysis and partitioning of sedimentary geochemical data sets: General principles and specific MATLAB scripts, Geochem. Geophys. Geosyst., 5, 1-6, 2013.

Pillai, A. A., Anoop, A., Prasad, V., Manoj, M. C., Varghese, S., Sankaran, M., and Ratnam, J.: Multi-proxy evidence for an arid shift in the climate and vegetation of the Banni grasslands of western India during the mid-to late-Holocene, The Holocene, 28, 1057-1070, 2018.

Pokharia, A. K., Kharakwal, J. S., and Srivastava, A.: Archaeobotanical evidence of millets in the Indian subcontinent with some observations on their role in the Indus civilization, J. Arch. Sci., 42, 442-455, 2014.

Ponton, C., Giosan, L., Eglinton, T. I., Fuller, D. Q., Johnson, J. E., Kumar, P., and Collett, T. S.: Holocene aridification of India, Geophys. Res. Lett., 39, L03704, https://doi.org/10.1029/2011GL050722, 2012.

Possehl, G. L.: Indus Age, The Beginnings, University of Pennsylvania Press, 1999.

Possehl, G. L.: The drying up of the Sarasvati: environmental disruption in South Asian prehistory, in: Environmental Disaster and the Archaeology of Human Response, edited by: Bawden, G. and Reycraft, M., Maxwell Museum of Anthropology, University of New Mexico, Paper no. 7, 2000.

Possehl, G. L.: The Indus Civilization: A Contemporary Perspective, Altamira Press, 2002.

Prasad, S. and Enzel, Y.: Holocene paleoclimates of India, Quat. Res., 66, 442-453, 2006.

Prasad, S., Anoop, A., Riedel, N., Sarkar, S., Menzel, P., Basavaiah, N., Krishnan, R., Fuller, D., Plessen, B., Gaye, B., Rohl, U., Wilkes, H., Sachse, D., Sawant, R., Wiesner, M. G., and Stebich, M.: Prolonged monsoon droughts and links to Indo-Pacific warm pool: a Holocene record from Lonar Lake, central India, Earth Planet. Sc. Lett., 391, 171-182, 2014.

Pruesse, E., Quast, C., Knittel, K., Fuchs, B. M., Ludwig, W., Peplies, J., and Glöckner, F. O.: SILVA: a comprehensive online resource for quality checked and aligned ribosomal RNA sequence data compatible with ARB, Nucleic Acids Res., 35, 7188-7196, 2007.

Purcell, J. E.: Climate effects on formation of jellyfish and ctenophore blooms: a review, J. Mar. Bio. Assoc. UK, 85, 461476, 2005.

Ratnagar, S.: Trading encounters: From the Euphrates to the Indus in the Bronze Age, Oxford University Press, 2004.

Ravenstein, E.: The laws of migration, J. Royal Stat. Soc., 48, 167235, 1885.

Ravenstein, E.: The laws of migration: second paper, J. Royal Stat. Soc., 52, 241-305, 1889.

Rho, M., Tang, H., and Ye, Y.: FragGeneScan: predicting genes in short and error-prone reads, Nucleic Acids Res., 38, e191, https://doi.org/10.1093/nar/gkq747, 2010. 
Roberts, N., Eastwood, W. J., Kuzucuoğlu, C., Fiorentino, G., and Caracuta, V.: Climatic, vegetation and cultural change in the eastern Mediterranean during the mid-Holocene environmental transition, Holocene, 21, 147-162, 2011.

Rosen, A. M.: Civilizing climate: social responses to climate change in the ancient Near East, Rowman Altamira Press, 2007.

Russell, J. M., Johnson, T. C., and Talbot, M. R.: A 725 yr cycle in the climate of central Africa during the late Holocene, Geology, 31, 677-680, 2003.

Sagoo, N. and Storelvmo, T.: Testing the Sensitivity of Past Climates to the Indirect Effects of Dust, Geophys. Res. Lett., 44, 5807-5817, 2017.

Saini, H. S., Tandon, S. K., Mujtaba, S. A. I., Pant, N. C., and Khorana, R. K.: Reconstruction of buried channel-floodplain systems of the northwestern Haryana Plains and their relation to the "Vedic" Saraswati, Curr. Sci., 97, 1634-1643, 2009.

Schug, G. R., Blevins, K. E., Cox, B., Gray, K., and MushrifTripathy, V.: Infection, disease, and biosocial processes at the end of the Indus Civilization, PLoS One, 8, e84814, https://doi.org/10.1371/journal.pone.0084814, 2013.

Schefuss, E., Kuhlmann, H., Mollenhauer, G., Prange, M., and Pätzold, J.: Forcing of wet phases in southeast Africa over the past 17,000 years, Nature, 480, 509, https://doi.org/10.1038/nature10685, 2011.

Schiebel, R., Zeltner, A., Treppke, U. F., Waniek, J. J., Bollmann, J., Rixen, T., and Hemleben, C.: Distribution of diatoms, coccolithophores and planktic foraminifers along a trophic gradient during SW monsoon in the Arabian Sea, Mar. Micropaleo., 51, 345-371, 2004.

Schneider, T., Bischoff, T., and Haug, G. H.: Migrations and dynamics of the intertropical convergence zone, Nature, 513, 4553, 2014.

Schulz, H., von Rad, U., and Ittekkot, V.: Planktic foraminifera, particle flux and oceanic productivity off Pakistan, NE Arabian Sea: modern analogues and application to the palaeoclimatic record, Geological Society, Special Pub., 195, 499-516, 2002.

Shadrin, A. M., Kholodova, M. V., and Pavlov, D. S.: Geographic distribution and molecular genetic identification of the parasite of the genus Ichthyodinium causing mass mortality of fish eggs and larvae in coastal waters of Vietnam, Doklady Bio. Sci., 432, 220-223, 2010.

Shaffer, J. G.: The Indus Valley, Baluchistan, and Helmand traditions: Neolithic through Bronze Age, in Chronologies in Old World archaeology, edited by: Ehrich, R. W., University of Chicago Press, Chicago, 1992.

Shanahan, T. M., McKay, N. P., Hughen, K. A., Overpeck, J. T., Otto-Bliesner, B., Heil, C. W., King, J., Scholz, C. A., and Peck, J.: The time-transgressive termination of the African Humid Period, Nat. Geosci., 8, 140-144, 2015.

Singh, A., Thomsen, K. J., Sinha, R., Buylaert, J. P., Carter, A., Mark, D. F., Mason, P. J., Densmore, A. L., Murray, A. S., Jain, M., and Paul, D.: Counter-intuitive influence of Himalayan river morphodynamics on Indus Civilisation urban settlements, Nat. Commun., 8, 1617, https://doi.org/10.1038/s41467-017-016439, 2017.

Singh, G.: The Indus Valley culture seen in the context of postglacial climatic and ecological studies in north-west India, Archeo. Phys. Anthrop. Oceania, 6, 177-189, 1971.
Sirocko, F.: Winter climate and weather conditions during the LittleIce-Age-like cooling events of the Holocene: implications for the spread of Neolithisation? in: 2200BC - A climatic breakdown as a cause for the collapse of the old world?, edited by: Meller, H., Arz, H. W., Jung, R., and Risch, R., Tugengen des Landesmuseum fur Vorgeschischte Halle, 12/II, 978-3-944507-29-3, 2015.

Smith, M. C., Singarayer, J. S., Valdes, P. J., Kaplan, J. O., and Branch, N. P.: The biogeophysical climatic impacts of anthropogenic land use change during the Holocene, Clim. Past, 12, 923-941, https://doi.org/10.5194/cp-12-923-2016, 2016.

Solomina, O. N., Bradley, R. S., Hodgson, D. A., Ivy-Ochs, S., Jomelli, V., Mackintosh, A. N., Nesje, A., Owen, L. A., Wanner, H., Wiles, G. C., and Young, N. E.: Holocene glacier fluctuations, Quaternary Sci. Rev., 111, 9-34, 2015.

Staubwasser, M., Sirocko, F., Grootes, P. M., and Erlenkeuser, H.: South Asian monsoon climate change and radiocarbon in the Arabian Sea during early and middle Holocene, Paleoceanography, 17, 1063, https://doi.org/10.1029/2000PA000608, 2002.

Staubwasser, M., Sirocko, F., Grootes, P. M., and Segl, M.: Climate change at the $4.2 \mathrm{ka}$ BP termination of the Indus valley civilization and Holocene south Asian monsoon variability, Geophys. Res. Lett., 30, 1425, https://doi.org/10.1029/2002GL016822, 2003.

Stein, M. A.: An archaeological tour of Gedrosia. Memoires of the Archaeological Survey of India, 43, Government of India Press, 1931.

Steinhilber, F., Abreu, J. A., Beer, J., Brunner, I., Christl, M., Fischer, H., Heikkilä, U., Kubik, P. W., Mann, M., McCracken, K G., and Miller, H.: 9,400 years of cosmic radiation and solar activity from ice cores and tree rings, P. Natl. Acad. Sci. USA, 109, 5967-5971, 2012.

Stuiver, M. and Braziunas, T. F.: Atmospheric 14C and centuryscale solar oscillations, Nature, 388, 405-407, 1989.

Stuiver, M., Reimer, P. J., and Reimer, R. W.: CALIB 7.1 [WWW program], available at: http://calib.org (last access: 1 January 2018), 2018.

Thomas, Z. A.: Using natural archives to detect climate and environmental tipping points in the Earth system, Quaternary Sci. Rev. 152, 60-71, 2016.

Thirumalai, K., Quinn, T. M., Okumura, Y., Richey, J. N., Partin, J. W., Poore, R. Z., and Moreno-Chamarro, E.: Pronounced centennial-scale Atlantic Ocean climate variability correlated with Western Hemisphere hydroclimate, Nat. Commun., 9, 392, https://doi.org/10.1038/s41467-018-02846-4, 2018.

Tierney, J. E., Pausata, F. S., and deMenocal, P. B.: Rainfall regimes of the Green Sahara, Sci. Adv., 3, e1601503, https://doi.org/10.1126/sciadv.1601503, 2017.

Uppala, S. M., Kållberg, P. W., Simmons, A. J., Andrae, U., Bechtold, V. D., Fiorino, M., Gibson, J. K., Haseler, J., Hernandez, A., Kelly, G. A., and Li, X... The ERA-40 re-analysis, Q. J. Roy. Meteor. Soc., 131, 2961-3012, 2005.

van Dijk, W. M., Densmore, A. L., Singh, A., Gupta, S., Sinha, R., Mason, P. J., Joshi, S. K., Nayak, N., Kumar, M., Shekhar, S., and Kumar, D. : Linking the morphology of fluvial fan systems to aquifer stratigraphy in the Sutlej-Yamuna plain of northwest India, J. Geophys. Res.-Earth, 121, 201-222, 2016.

Van Hengstum, P. J., Donnelly, J. P., Fall, P. L., Toomey, M. R., Albury, N. A., and Kakuk, B.: The intertropical convergence zone modulates intense hurricane strikes on the western North Atlantic 
margin, Sci. Rep., 6, 21728, https://doi.org/10.1038/srep21728, 2016.

von Rad, U., Schaaf, M., Michels, K. H., Schulz, H., Berger, W. H., and Sirocko, F.: A 5000-yr record of climate change in varved sediments from the oxygen minimum zone off Pakistan, Northeastern Arabian Sea, Quat. Res., 51, 39-53, 1999.

Wang, L., Li, J., Lu, H., Gu, Z., Rioual, P., Hao, Q., Mackay, A. W., Jiang, W., Cai, B., Xu, B., Han, J., and Chu, G.: The East Asian winter monsoon over the last 15, 000 years: its links to highlatitudes and tropical climate systems and complex correlation to the summer monsoon, Quaternary Sci. Rev., 32, 131-142, 2012.

Wang, Y., Liu, X., and Herzschuh, U.: Asynchronous evolution of the Indian and East Asian Summer Monsoon indicated by Holocene moisture patterns in monsoonal central Asia, Earth Sci. Rev., 103, 135-153, 2010.

Wanner, H., Beer, J., Bütikofer, J., Crowley, T. J., Cubasch, U., Flückiger, J., Goosse, H., Grosjean, M., Joos, F., Kaplan, J. O., and Küttel, M.: Mid-to Late Holocene climate change: an overview, Quaternary Sci. Rev., 27, 1791-1828, 2008.

Weber, S. A.: Archaeobotany at Harappa: indications for change, in: Indus Ethnobiology, New Perspectives from the Field, edited by: Weber, S. A. and Belcher, W. R., Lexington Books, 175-198, 2003.

Weber, S. A., Barela, T., and Lehman, H.: Ecological continuity: an explanation for agricultural diversity in the Indus Civilisation and beyond, Man and Environment, 35, 62-75, 2010.

Werner, D.: The biology of diatoms, Vol. 13, University of California Press, California, 1977.
Wirth, S. B., Glur, L., Gilli, A., and Anselmetti, F. S.: Holocene flood frequency across the Central Alps-solar forcing and evidence for variations in North Atlantic atmospheric circulation, Quaternary Sci. Rev., 80, 112-128, 2013.

Wirtz, K. W., Lohmann, G., Bernhardt, K., and Lemmen, C.: Mid-Holocene regional reorganization of climate variability: Analyses of proxy data in the frequency domain, Palaeogeogr. Palaeocl., 298, 189-200, 2010.

Worden, A. Z., Follows, M. J., Giovannoni, S. J., Wilken, S., Zimmerman, A. E., and Keeling, P. J.: Rethinking the marine carbon cycle: Factoring in the multifarious lifestyles of microbes, Science, 347, 735-745, 2015.

Wright, R. P.: The Ancient Indus: Urbanism, Economy and Society, Cambridge University Press, Cambridge, 2010.

Wright, R. P., Schuldenrein, J., and Mughal, M. R.: South Asian Archaeology 2001, edited by: Jarrige, C. and Lefèvre, V., CNRS, Paris, 327-333, 2005.

Wright, R. P., Bryson, R., and Schuldenrein, J.: Water supply and history: Harappa and the Beas regional survey, Antiquity, 82, 3748, 2008.

Wurtzel, J. B., Abram, N. J., Lewis, S. C., Bajo, P., Hellstrom, J. C., Troitzsch, U., and Heslop, D.: Tropical Indo-Pacific hydroclimate response to North Atlantic forcing during the last deglaciation as recorded by a speleothem from Sumatra, Indonesia, Earth Planet. Sc. Lett., 492, 264-278, 2018.

Yashpal, S. B., Sood, R. K., and Agarwal, D. P.: Remote sensing of the 'Lost' Sarasvati River, P. Ind. Nat. Sci. Acad.-Earth Planet. Sci., 89, 317-331, 1980.

Zielinski, G. A., Mayewski, P. A., Meeker, L. D., Whitlow, S., and Twickler, M. S.: A 110,000-yr record of explosive volcanism from the GISP2 ice core, Quat. Res., 45, 109-118, 1996. 